\title{
A CRACK IN EVERYTHING: Restorative Possibilities OF Plea-Based Sentencing Courts
}

\author{
SIMON OWEN ${ }^{*}$
}

Restorative justice, as a philosophy and set of practices, has traditionally been conceived of as existing separate from, indeed in opposition to, the more retributive ethic of mainstream, court-based justice processes. Considered as such a polarized alternative, restorative justice has largely been unable to dislodge the dominant hold that formal, professionally managed public courts maintain over the resolution of criminal wrongs. Other commentators, however, argue that restorative and retributive concepts of justice are not necessarily mutually exclusive. This article explores court-based sentencing processes through a restorative lens, and suggests that while Canadian law formally privileges a retributive approach to sentencing, it also endorses practices that are more resonant with restorative values. In practice, sentencing courts that draw energy and guidance from restorative justice principles are more successful at including offenders in dialogues and determinations of just outcomes. Thus, a formally retributive sentencing framework actually benefits from the incorporation of restorative principles and practices. The marriage of these concepts of justice is, however, hampered by the antagonistic concerns of efficiency and uniformity in sentencing.
En tant que philosophie et ensemble de pratiques, la justice réparatrice est traditionnellement considérée comme étant séparée, voire opposée, au courant dominant punitif des procédures judiciaires. Considérée comme une forme polarisée, la justice réparatrice n'a pour ainsi dire pas réussi à déloger la forme dominante que les tribunaux publics officiels gérés professionnellement maintiennent pour régler les transgressions criminelles. D'autres observateurs font cependant valoir que les concepts de réparation et de rétribution de la justice ne soient pas nécessairement exclusifs. Cet article explore la détermination de la peine du point de vue de la réparation et laisse entendre qu'alors que le droit canadien accorde officiellement la préférence à la rétribution, il appuie aussi les pratiques qui relèvent davantage de la réparation. Dans la pratique, le tribunal infligeant la peine qui s'inspire des principes de justice réparatrice et qui se laisse guider en conséquenceréussit mieux à inclure les contrevenants dans le dialogue et la détermination de résultats justes. Ainsi, un cadre officiel de peines punitives profite de l'incorporation des principes et des pratiques de la justice réparatrice. La combinaison de ces concepts de justice est cependant gênée par des préoccupations antagonistes sur l'efficacité et l'uniformité dans la détermination des peines.

\section{TABLE OF CONTENTS}

I. INTRODUCTION . . . . . . . . . . . . . . . . . . . . . . . . . . . . . . . 848

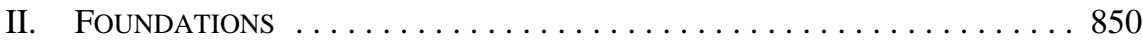

A. The Foundation OF GUILT IN CANADIAN

CRiminal Justice: Moral ResPonsibility . . . . . . . . . . . . 850

B. THE Foundation OF PUNISHMENT IN CANADIAN LAW:

RETRIBUTIVE PROPORTIONALITY . . . . . . . . . . . . . . . . 853

C. THE FUNDAMENTAL EXPRESSIVENESS OF

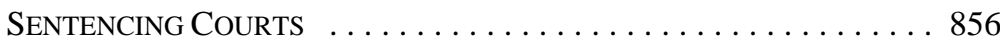

III. The Challenges of PleA-BAsed CRiminal Justice . . . . . . . . . . . . 859

A. A SNAPSHOT OF BRITISH COLUMBIA'S

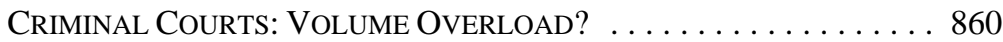

LL.M. (British Columbia). Simon currently practices criminal defence law in Thunder Bay and Sioux Lookout, Ontario. He is interested in the potential of restorative justice processes within public institutions, particularly in the area of criminal, intercultural justice. His academic and professional explorations have taken him from the Coast Salish territories on Vancouver Island, to South Africa and New Zealand, and back to Canada’s Inuit, Gitxsan Ojibway, and Cree Nations. 
B. The Court System's Procedural SAnctions $\ldots \ldots \ldots \ldots$. . . . 862

C. The Contorting Cultures of Courts . . . . . . . . . . . 863

D. The Fraught Nature of the Plea Itself . . . . . . . . . . . . . . . 864

E. THE ENDURING INFLUENCE OF NEGOTIATED

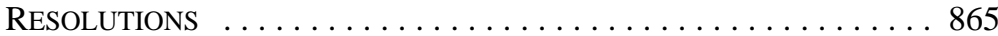

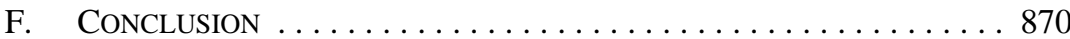

IV. The Restorative Profiles of Three Criminal Courts $\ldots \ldots \ldots . . .871$

A. Court 102 at 222 Main Street, Vancouver . . . . . . . . . . 872

B. VANCOUVER'S DOWNTOWN COMMUNITY COURT . . . . . . . . . . . 877

C. First NATiOnS COURT $\ldots \ldots \ldots \ldots \ldots \ldots \ldots \ldots 1$

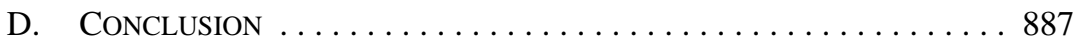

V. CONCLUSION ............................. 891

\section{INTRODUCTION}

Somewhat lamentably for its advocates, restorative justice, as a philosophy and set of practices, seems stalled on the margins of criminal justice in Canada. With comparatively miniscule budgets and staffs often composed largely of volunteers, restorative justice programs have produced generally encouraging outcomes ${ }^{1}$ in the realm of the non-violent, youth, and first offender minor offences most commonly assigned to them. They are significantly limited, however, by a resistance to their expansion that can best be understood as ideological. This resistance, sometimes stated explicitly but more often evident in the simple persistence of the status quo, refutes the thesis that most offences or offenders are responsive to or deserving of "restoration," or that community-based processes can effectively denounce wrongdoers and protect society. ${ }^{2}$ At base, perhaps, is the reluctance of an established legal apparatus, founded upon and animated by authoritative power, to give way to decentralized, non-state-based approaches, however promising they may be. ${ }^{3}$

This article is not intended to argue for the expansion of community-based restorative justice programs, however worthwhile a goal this may be. Instead, I inquire into the mainstream criminal legal system itself, specifically the law and practice of sentencing, to ask whether any of restorative justice's values are finding purchase in a formally retributive, state-based environment. In doing so I take a broad, or maximalist view of restorative justice, asking how its "tent" of values may encompass or influence court-based processes for resolving crime within the mainstream system. ${ }^{4}$ This approach will inevitably stretch the

See Jeff Latimer, Craig Dowden \& Danielle Muise, “The Effectiveness of Restorative Justice Practices: A Meta-Analysis" (2005) 85 The Prison Journal 127, for the most comprehensive recent review of restorative justice program effectiveness.

2 See generally the critique of the “dominant” system articulated in Herman Bianchi, Justice as Sanctuary: Toward a New System of Crime Control (Bloomington: Indiana University Press, 1994). Bianchi states: "Reversion, conversion, repentance, forgiveness, atonement, reconciliation, penitence: all these concepts are entirely ignored in the punitive model of criminal law.... It is not lack of good will that causes administrators of punitive justice to be unacquainted with such concepts. It is simply the reality that the punitive system does not allow for them” (at 41-42).

3 It must also be noted here that some substantive critiques have been made of restorative justice's ability to further its objectives while protecting the interests of vulnerable persons: see e.g. Annalise Acorn, Compulsory Compassion: A Critique of Restorative Justice (Vancouver: UBC Press, 2004).

4 See Susan Sharpe, “How Large Should the Restorative Justice 'Tent' Be?” in Howard Zehr \& Barb Toews, eds., Critical Issues in Restorative Justice (Monsey, N.Y.: Criminal Justice Press, 2004) 17 at 20. 
concept of restorativeness beyond what many restorative justice advocates may be comfortable with, or able to support. As will be seen, many of the predicates upon which state-based criminal justice operates are highly resistant to the approaches, concerns, and outcomes that are commonly espoused by advocates as restorative. Nevertheless, I set out to explore the restorative possibilities that do exist within court-based resolution processes, even if these possibilities offer only partial or insufficient succour for those who would wish to see such values fully flourish.

In Part II, I discuss three constituent features of state-based criminal justice in Canada that hold particular relevance for the viability of restorative values. These are the criminal law's fundamental concern for moral ordering, its primarily retributive approach to punishment, and its endorsement of sentencing courts as communicative forums. By attending to the mainstream system's jurisprudential and structural framework, it is possible to perceive some deeply ingrained opportunities for restorative values to inform the justice that courts conduct, as well as some equally deep-seated impediments standing in the way of this process.

Part III moves from a theoretical framework to consider some of the more practical challenges faced by restorative values in influencing the court-based resolution of criminal wrongs. In this Part, I concentrate on the plea-based nature of criminal justice, identifying the production and discharge of guilty pleas as significant factors modulating sentencing courts' ability to engage with the responsibility of offenders.

Finally, Part IV presents empirical findings of an observation of three sentencing courts in British Columbia, in regards to which each may be seen as reflecting certain restorative values, most particularly the dialogic engagement of offenders in discussions about their responsibility for criminal conduct. My findings reveal that while some sentencing processes are more interested in efficiency than effective communication, others are audibly striving to incorporate consideration of offenders' perspectives and contextual personhood into their practices.

Before commencing on these inquiries, it is important to introduce the restorative values to which I will be referring. Howard Zehr, in his classic primer The Little Book of Restorative Justice, identifies approaches to resolving wrongs as located on a continuum, from "fully restorative” to "pseudo- or non-restorative” practices. ${ }^{5}$ He poses six key questions for analyzing the extent to which a particular model is restorative:

1. Does the model address harms, needs, and causes?

2. Is it adequately victim-oriented?

3. Are offenders encouraged to take responsibility?

4. Are all relevant stakeholders involved?

5. Is there an opportunity for dialogue and participatory decision-making?

6. Is the model respectful to all parties? ${ }^{6}$

Howard Zehr, The Little Book of Restorative Justice (Intercourse, Pa.: Good Books, 2002) at 54-55. Ibid. at 55. 
These criteria do not necessarily encompass all of the considerations or qualities that a given process might espouse as restorative, but they form useful touchstones for this article's research into court-based practices. Zehr also recognizes that the values and motivations that propel restorative and retributive approaches to justice are not necessarily opposed: "Both retributive and restorative theories of justice acknowledge a basic moral intuition that a balance has been thrown off by a wrongdoing.... Both approaches argue that there must be a proportional relationship between the act and the response."7

These approaches tend to differ, Zehr suggests, in the "currency" by which they expect balance to be restored. ${ }^{8}$ Where retributive justice prescribes a just measure of pain, restorative approaches stress the acknowledgment of harms, combined with the active encouragement of offenders to act responsibly in relation to the harm that they have caused. As will be further explored in this article, while Canada's state-based system of criminal justice may formally privilege retributive punishment, it also provides support for this approach to be tempered by restorative values.

Clearly, the mere fact that a process is controlled by the state rather than a local community does not, by itself, dictate its ability to endorse or reflect Zehr's criteria of "restorativeness." This article proceeds on the understanding that sentencing courts, even while creatures of a state-based system, are always situated (if not rooted) in local communities, and have important responsibilities to the particular individual contexts that they encounter. My hypothesis is that sentencing courts that are able to openly address, integrate, and communicate their responsibilities to both the state-based law and the local human needs that are caught up in almost every crime will be engaged in furthering restorative values, even if in an insufficient or incomplete way. Observing the actual practices of different sentencing courts in this regard is a way of testing this presumption, while keeping in mind that to a large extent the "restorativeness" of a given process rests in the eyes of its participants, as well as beholders. While I use some objective measures in this empirical investigation, my overall findings and conclusions are qualitative and, necessarily, partial. The parameters and limitations of this research are discussed at greater length at the outset of Part III, below. I begin, however, with a survey of the jurisprudential grounds upon which state-based sentencing processes are built.

\section{FOUNDATIONS}

\section{A. The Foundation OF Guilt in CANAdian CRIMINAL JusticE: MORAL RESPONSIBILITY}

To be a crime, any given conduct must be cast as wrong. The first place that we must turn to for evidence for this proposition is Canada's constitutional division of legislative authority, and the federal power over criminal law that falls under s. 91(27) of the Constitution Act, $1867 .{ }^{9}$ Unlike states with a unitary or non-constitutional political system, the federal government is obligated to define and justify the parameters of its criminal law-

Ibid. at 59.

Ibid.

(U.K.), 30 \& 31 Vict., c. 3, reprinted in R.S.C. 1985, App. II, No. 5. 
making power. The link of what is properly criminalized with what is morally wrong began to take shape early in the Supreme Court of Canada's jurisprudence regarding s. 91(27). In Reference Re Validity of Section 5(a) of the Dairy Industry Act, ${ }^{10}$ the Court restricted the purpose of criminal legislation, as a requirement of its validity, to combatting "some evil or injurious or undesirable effect upon the public."11 These effects were broadly construed, however, to attach to a wide range of "social, economic or political interests,"12 and so long as the state could point to the protection of such an interest as underpinning a given piece of criminal legislation, it was not required to articulate any further, explicitly "moral"13 justification for its classification as such. The "wrongness" of a criminal act could thus, in law, have remained an unquestioned, even irrelevant matter; perhaps self-evident in most cases, but beyond the realm of contestation in the crucial few where it might have made a difference.

With the advent of the Canadian Charter of Rights and Freedoms, ${ }^{14}$ however, the Supreme Court was given a significantly more expansive opportunity to elaborate upon the criminal law's requisite procedural and purposive content, as applied to the individual rights and freedoms that these laws necessarily curtail. According to the principles of fundamental justice that the Court has outlined thus far, criminal laws cannot be "arbitrary or irrational."15 They cannot impose punishment without a minimum of proven fault. ${ }^{16}$ They cannot be unduly vague. ${ }^{17}$ And they cannot, as I argue here, prohibit conduct that a state has not established as being, according to a "significant societal consensus," morally wrong. ${ }^{18}$

Some of the most fundamental opportunities for, and impediments to, engaging restorative values in criminal justice may be found within this requirement. A social consensus of what constitutes wrongdoing is, of course, a necessary guide in all but the most authoritarian, legalistic states, and Canada's constitution guarantees it to be neither. In respect of most criminal offences, moreover, local understandings of wrongful conduct (arguably crucial to the effectiveness of both retributive and restorative responses thereto) would seem to be reflected in criminal legislation. It is virtually unquestioned, for example, that absent extraordinary circumstances, intentionally causing physical injury to another human being is criminally wrong. Two important features of Canada's criminal legal structure, however, potentially weaken the common, mutually supportive foundation of state and locally-based conceptions of what is sufficiently wrong to prompt a public response.

First, notwithstanding the normative diversities inherent in a multicultural, multinational society, Canadian criminal law is characterized by its universality. The federal Criminal $\operatorname{Code}^{19}$ prescribes precisely which conduct is criminal, and the route that must be followed

(1948), [1949] S.C.R. 1 [Margarine Reference].

Ibid. at 49.

Ibid.

Ibid.

Part I of the Constitution Act, 1982, being Schedule B to the Canada Act 1982 (U.K.), 1982, c. 11 [Charter].

R. v. Malmo-Levine; R. v. Caine, 2003 SCC 74, [2003] 3 S.C.R. 571 at para. 135 [Malmo-Levine].

Reference Re Section 94(2) of the Motor Vehicle Act (British Columbia), [1985] 2 S.C.R. 486 at 517, 522.

See e.g. R. v. Nova Scotia Pharmaceutical Society, [1992] 2 S.C.R. 606 at 643.

Malmo-Levine, supra note 15 at para. 113.

R.S.C. 1985 , c. C-46. 
by the prosecuting state in establishing a given act's culpable commission. The law's universality, constitutionally enabled by s. 91(27) of the Constitution Act, $1867,{ }^{20}$ creates an overarching, undifferentiated fabric that blankets the country. What is unlawful in Corner Brook is also unlawful in Montreal and Igloolik, whether the act in question is simple possession of marijuana or first degree murder. ${ }^{21}$ The subject matter that sentencing courts must process, therefore, while usually consistent with local norms regarding wrongdoing, is not guaranteed to be so; the required social consensus of what is appropriately criminalized is debated and created at the national political level.

Second, restorative values are geared towards responding to interpersonal harms, as is explicitly reflected in the first of Zehr's six questions of restorativeness. Canada's criminal law, however, encompasses conduct that, at best, fits rather awkwardly under the rubric of harm. This awkwardness was perhaps most directly encountered by the Supreme Court in Malmo-Levine, ${ }^{22}$ where it tackled the issue of whether the state can criminally prohibit "harmless" conduct.

In this case, a 6-3 majority held that, while the criminal prohibition of marijuana may be a dubious or disproportionate means of addressing the harm caused, it was confirmed as constitutionally valid as a matter of law, not of policy. In arriving at this conclusion, the majority refused to accept the appellants' assertion of the classic libertarian "harm principle" as a principle of fundamental justice under s. 7 of the Charter. ${ }^{23}$ Justices Gonthier and Binnie, writing for the majority of the Court, ruled that this theory's articulation of what justifies state intervention - namely, and solely, conduct that causes "clear and tangible harm to the rights and interests of others" ${ }^{24}$ — provided an insufficiently comprehensive basis upon which other justifiable aims of the criminal law could be directed. Their decision quoted the British legal philosopher H.L.A. Hart in defence of criminal legislation as properly pertaining to a more "complex" spectrum of interests than just harm:

Mill's formulation of the liberal point of view may well be too simple. The grounds for interfering with human liberty are more various than the single criterion of 'harm to others' suggests: cruelty to animals or organizing prostitution for gain do not, as Mill himself saw, fall easily under the description of harm to others. Conversely, even where there is harm to others in the most literal sense, there may well be other principles limiting the extent to which harmful activities should be repressed by law. So there are multiple criteria, not a single criterion, determining when human liberty may be restricted. ${ }^{25}$

Supra note 9.

Within this "universal" legal structure, it must be noted that significant administrative variations do exist. By virtue of s. 92(14) of the Constitution Act, 1867, ibid., Canada's founding constitutional document, each province is authorized to articulate its own regime for how the operation of criminal justice is best organized, and there are also important variances contained in provincial and local policing and prosecutorial policies regarding the realization of the overarching law's demands and aspirations. As we shall see, the latitude that this arrangement allows can be extremely important for the criminal justice system's intended coherence; but it is this intentionality that I magnify and scrutinize as one of the system's foundations.

Supra note 15.

See John Stuart Mill, On Liberty, ed. by Currin V. Shields (New York: Liberal Arts Press, 1956).

Malmo-Levine, supra note 15 at para. 107.

H.L.A. Hart, "Immorality and Treason" in Richard A. Wasserstrom, ed., Morality and the Law (Belmont, Cal.: Wadsworth, 1971) 49 at 51, cited in ibid. at para. 109 [emphasis in original]. 
While the prevailing judgment in this case explicitly disavowed the paramountcy of the harm principle per se, it did cast the criminal law as necessarily targeting, if not solely harm to others, then harm to "some fundamental conception of morality," 26 so long as such standards were proven to be "integral to our ideas of civilized society."27 The requirement of some harm to some valid state interest, therefore, was implicitly upheld. The majority in Malmo-Levine did find that the state had sufficiently established that unregulated marijuana use did constitute harm to a valid state interest (here, the protection of vulnerable groups of actual or potential users) that was more than trivial or insignificant, thus justifying its continued prohibition on this basis.

The difficulty that criminal prohibitions of so-called harmless or victimless conduct pose for courts that wish to incorporate restorative values into their resolution practices is quite simple: the notion of wrong upon which these crimes are established is determined according to the interests of a faceless, often abstract state. There is thus, in these cases, scant ground upon which resonant participant dialogues can be founded; they are much more suited to routine, bureaucratized responses. While this concern strengthens the argument that statebased criminal justice does not provide sustenance for restorative values, it applies as an exception to a more general truth. Certainly, the Criminal Code is far from being a completely cohesive or coherent piece of legislation. It contains provisions based on antiquated or discredited moral principles, and offences where criminalization arguably causes more harm than it prevents. But it is by the cases on the penumbra, I suggest, which are most likely to fall into disuse or eventually be abolished altogether, that the general proposition is proven: the vast majority of criminal offences in Canada are predicated on a theory of harm, a core of normative moral opprobrium that is (intended to be) common to the diverse constituencies that the law binds. Not all harms are crimes, but (almost) all crimes are also, in an apprehended or actual sense, in a strict or expansive understanding of the term, "harmful," and, by the establishment of this connection, thereby wrong.

It is with this raw material that all resolution processes work. However, just because a state has appropriately proscribed conduct that is well recognized as harmful or wrong does not mean that its responses to such conduct will be reflective of anything approaching restorative values. Below, I consider whether the retributive basis of Canadian sentencing law leaves any room for courts to function in restorative ways.

\section{B. The Foundation of Punishment in Canadian Law: RETRIBUtive Proportionality}

A mélange of rationales is discernable in Canada's sentencing schema. In no particular order of importance, the Criminal Code endorses:

- Denunciation of wrongful conduct; ${ }^{28}$ 
- $\quad$ Deterrence, both specific (vis-à-vis the offender) and general (vis-à-vis others in society); ${ }^{29}$

- Incapacitation of offenders, “where necessary”;30

- $\quad$ Rehabilitation; ${ }^{31}$

- Reparations to victims or the community; ${ }^{32}$

- $\quad$ Promotion of "a sense of responsibility in offenders, and acknowledgment of the harm done to victims and to the community";33

- $\quad$ Parity, vis-à-vis “similar” offences, offenders, and circumstances; ${ }^{34}$

- Constrained totality (so that consecutive offences are not “unduly long or harsh”); and

- $\quad$ Restraint in the use of imprisonment if less restrictive sanctions are appropriate ${ }^{36}$ and "with particular attention to the circumstances of aboriginal offenders."37

The Criminal Code also generally allows for punishments to "be increased or reduced to account for any relevant aggravating or mitigating circumstances relating to the offence or the offender," 38 and enumerates a non-exhaustive list of aggravating (but not mitigating) factors.

One principle, however, is advanced as an overarching guide to balancing these diverse and potentially conflicting impetuses. Section 718.1, the "fundamental principle" of sentencing, states that "[a] sentence must be proportionate to the gravity of the offence and the degree of responsibility of the offender." ${ }^{39}$ A court that seeks to impose a fair sentence according to this framework must therefore determine not only the "badness" of the crime, but also the "blameworthiness" of the offender. While a range of maximum and (increasingly) minimum sentences, as well as previous decisions in similar cases offer presumptive boundaries and benchmarks in this regard, punishments are meant to fit the unique characteristics of the criminal as well as the crime. Canada's sentencing courts, while authorized to bring a large degree of discretion to the imposition of punishment, are thus guided by a conceptual framework that privileges the morally formulated concern of "proportionality." 
Two distinct moral theories, both reflected in the Criminal Code, claim normative space in this area: utilitarianism and retributivism. ${ }^{40}$ Broadly, utilitarianism suggests that society ought to seek to improve its overall welfare, while retributivism posits that this end (even supposing that it can be agreed upon and realized) ought not to be achieved by "unjust" means. Most appositely to this discussion, retributivism counsels us to respect a pre-existing, overriding concept of human dignity, and thus disavow any criminal law, process, or punishment that undermines this moral absolute. Looked at another way, while utilitarian rationales for punishment are primarily reductive, or aimed at minimizing future criminal harms, retributive rationales are concerned with what offenders deserve (no less and, even more certainly, no more). Although it is shaded and moderated by our evolving social mores, liberal constitutional principles, and other sentencing objectives, Canada's express privileging of proportional punishment takes its moral energy from the retributive principle of just deserts. According to the Criminal Code and leading jurisprudence, ${ }^{41}$ sentences must be appropriately and contextually balanced by way of the fundamental (retributive) principle of proportionality. But what, in practice, does this require sentencing courts to consider?

The proportionality that is meant to guide the imposition of punishments can be interpreted in two very different ways. The more narrow application of this principle, based on a kind of formal equality, would result in rigid sentencing gradations according to the adjudged gravity of the offence. This brand of strict retributivism is evident in jurisdictions that employ a point or tariff scale to determine the appropriate amount of punishment, ${ }^{42}$ where the worse the crime, or the more aggravating the circumstances of its commission, the harsher the penalty. While certain aspects of the Criminal Code's sentencing provisions lend support to this approach, others, including the second clause of the proportionality principle, endorse a broader interpretation. Through this lens, the establishment of liability for a given crime is merely a base prerequisite for more nuanced considerations of an offender's responsibility for the offence, at which stage virtually anything in one's personal or social situation has potential importance. Proponents of more socially just responses to criminal wrongdoing are attracted by such a "substantive equality" reading of proportionality: Michael Tonry suggests that justice cannot be extended to minorities or the poor without this "compassionate" interpretation of culpability, ${ }^{43}$ and Barbara Hudson argues that, especially in regards to offences borne from socio-economic poverty, a person's “choice” to commit crime ought not to be understood in black and white terms. Hart's notion of crime as requiring a "fair opportunity to resist," she suggests, should be expanded to encompass culpability reductions "in circumstances such that conformity with the law [is] more difficult than for most people." 44

George P. Fletcher, The Grammar of Criminal Law: American, Comparative, and International (New York: Oxford University Press, 2007) vol. 1, c. 5.

See R. v. Proulx, 2000 SCC 5, [2000] 1 S.C.R. 61 at para. 82.

This approach is reflected, although only to an advisory extent, in the sentencing guidelines contained in the United States Penal Code 28 U.S.C. §§ 991-98 (establishing the United States Sentencing Commission).

Michael Tonry, "Individualizing Punishments” in Andrew von Hirsch, Andrew Ashworth \& Julian Roberts, eds., Principled Sentencing: Readings on Theory and Policy (Oxford: Hart, 2009) 354.

Barbara A. Hudson, "Justice and Difference” in von Hirsch, Ashworth \& Roberts, ibid. 366 at 369. The reality that most crime is committed by those on society's margins, however, must be coupled with the equally inescapable fact that the majority of those harmed by crime are also mired in socio-economic inequality. Those who seek to have sentences reflect justice for offenders, therefore, must contend with the possibility that furthering this cause may infringe on the concept of justice interpreted by victims. Indeed, as Hudson acknowledges, this is an abiding difficulty, and sometimes it is simply not possible to "do justice" to both offenders and victims in the same part of the criminal justice system, much less 
In the interminable debate of parity versus particularity, however, both of which are reflected in the Criminal Code's objectives, the fundamental principle of proportionality seems to most favour the latter concern, and the specific deserts of specific offenders. The balance aimed at by this individualized assessment, while weighing in the harm to victims and the needs and values of society, is most dependent upon individually ascribed moral blame, or what punishment a given offender "justly deserves."

The above outline of Canada's sentencing framework strongly suggests that the statebased criminal justice system is driven by retributive ideals. This formal reality certainly serves to forestall or constrict opportunities for restorative values to inform this system's operation. As Zehr suggests, however, retributive and restorative justice goals need not be in complete opposition. Neither, I suggest, do the routes each theory takes to get there. Below, I focus in particular on the emphasis that sentencing law places on the communicative importance of courts' work in the resolution of criminal wrongs.

\section{The Fundamental EXPRESSIVEnEsS OF SENTENCING Courts}

The mechanism of assigning criminal responsibility is designed to both call down and control the moral opprobrium that flows, from a diversity of social sources, onto offenders upon their conviction. While they are ultimately unable to be completely so, criminal courts try, at least, to provide the authoritative voice through which society expresses its disapproval of criminal conduct, both to offenders and to itself.

There is evidence for this ambition in the sentencing provisions of the Criminal Code. The first enumerated purpose of sentencing is to "denounce unlawful conduct," 45 and the last is "to promote a sense of responsibility in offenders, and acknowledgment of the harm done to victims and to the community." ${ }^{46}$ While, in theory, these aims may be substantially accomplished by the punishment itself, certain core procedures, long upheld by courts as essential to their legitimacy and function, indicate that something more directly communicative is endorsed. Defendants must personally appear before the court to receive their sentences, which are orally delivered from the judge's bench. Members of the community are allowed to witness this public proceeding, and submissions are invited from the prosecutor, defence counsel, the offender, and any victim of the offence. In most major respects, the process by which a person's sentence is communicated would appear to be secondary in importance, at least in terms of the legislated purposes and principles at play, only to the punishment itself.

A number of theorists support this orientation, ascribing and prescribing it normative force. R.A. Duff has articulated a comprehensive communicative theory of punishment, which he argues is most appropriate for a liberal polity that defines offenders as responsible moral agents (as, I argue, does Canada’s). Such a society’s criminal law, he asserts, cannot

maintain consistent standards across the spectrum of situations and personalities that play into the determination of punishments. It would seem to come down to a matter of judicial preferences, which all theorists may be able to agree allows for considerable compassion or harsh treatment, depending on whose interests - victim, offender, community, or a combination of all — are privileged by a sentencing court.

$45 \quad$ Supra note 19, s. 718(a).

Ibid., s. 718(f). 
merely attempt to coerce conformity and obedience through punishment. Presuming as it does a shared community of values, which locates and addresses offenders as wayward members thereof, ${ }^{47}$ the law must instead

aim ... to persuade them to refrain from criminal wrongdoing because they realize that it is wrong. That aim can of its nature be achieved only by a communicative process that seeks to bring citizens to recognize and to accept not just that certain kinds of conduct are 'prohibited' by the law ... but that and why such conduct is wrong. 48

Regardless of the sensibility that particular offenders may bring into or, indeed, as responsible moral agents, take from a criminal court's sentencing process (whether shame, openness, indifference, or defiance), the process itself must advance the same invitation. Albeit usually embedded in the "hard treatment" of punishment, ${ }^{49}$ Duff characterizes this invitation as fundamentally offering the opportunity of repentance and eventual reintegration into the normative community. Furthermore, in order to best ensure that offenders are able to hear (if not ultimately accept) the moral message that a sentencing court seeks to send, this forum must attend just as carefully to how this message is communicated: "If the defendant is to be answerable, she must be called to answer in a language that she can understand.... What someone hears, or can be reasonably expected to hear, when he is addressed depends not just on the content of what is said, but on the context in which it is said, and the accent in which it is spoken." 50

What this would require in practical terms, of course, differs between communities, but the idea is relatively straightforward: criminal courts have important normative responsibilities, which ought to be communicated in the most comprehensive and comprehensible way possible. Further, this should be a dialectical process, which "aims not merely to communicate with the offender, but also to provide a means by which she can communicate apologetically with her victim and the community."51

Duff's orientation is supported, in part, by Christopher Bennett. ${ }^{52}$ Bennett perceives a "crisis of meaning" in the criminal justice system, in which "it is not clear what the system is actually meant to be doing, what that overall purpose of criminal justice is - or whether

R.A. Duff, Punishment, Communication, and Community (New York: Oxford University Press, 2001)

[Duff, Punishment, Communication, and Community]. At 68, he states that

[a] community can exist only if most of its members recognize themselves as members of it and share in those values and aspirations. The law speaks to such members in what they can hear as their own voice - in terms to values to which they are already committed and of what they owe to others whom they already recognize as their fellow citizens [emphasis in original].

Although there will always be those who dissent from or reject this normative community, Duff insists that "we try to find ways of bringing them to recognize a certain kind of fellowship and to accept the moral demands that it makes" (at 70). Failures are, of course, inevitable, but the attempt is essential given that it is the community's moral norms that are being applied to the offender, and justify their punishment. In Part III, below, I discuss some of the complexities of this perspective as it relates to the Canadian context. Ibid. at 81 [emphasis in original].

R.A. Duff, "Punishment, Retribution, and Communication" in von Hirsch, Ashworth \& Roberts, supra note 43,126 at 129 .

Duff, Punishment, Communication, and Community, supra note 47 at 189, 192 [footnote omitted]. Ibid. at 159 [emphasis in original].

Christopher Bennett, The Apology Ritual: A Philosophical Theory of Punishment (Cambridge: Cambridge University Press, 2008). Although written from a British context, I take Bennett's theoretical critique and prescriptions to apply to Canada's situation as well. 
the officially given purposes are really compelling ones."53 For Bennett, the state has to (continually) justify its coercive involvement in people's lives, which can only be grounded in the repair of political community, once ruptured: "The concern of the criminal law is with the maintenance of a certain relationship between citizens. Unless what citizens do offends the standards internal to this political relationship the criminal law has no business with the morality of its citizens' actions." 54

Once such an offence has been established, the presiding institution is called upon to channel and express a collective duty: "symbolically adequate" condemnation, which "impose[s] on the offender a duty to make amends of the sort that he would be spontaneously motivated to make were he genuinely sorry for what he has done." 55

Both Bennett and Duff place emphasis on a judge's authority to look, as deeply as is felt necessary, into the context and characteristics of the wrong and wrongdoer. This standpoint, indeed, is true of all who imbue courts with the responsibility of assessing and addressing the moral gaps a given offence opens between members of a community and/or between individuals and the state. It is also a perspective that has apparently been accepted in Canadian law, as reflected in the various inherent and statutory mechanisms designed to afford courts the scope to make such deep, contextual enquires. These include pre-sentence reports, ${ }^{56}$ victim impact statements, ${ }^{57}$ and the invitation that offenders are given in every case to personally address the court before they are sentenced. ${ }^{58}$

Sentencing hearings are where all relevant participants in a given case gather to hear and be heard, to make submissions and present evidence, to argue for or against a particular outcome, or to try to convince a judge why a negotiated settlement should be approved. If there is any occasion for substantive, contextual moral engagement in criminal law, sentencing hearings are uniquely well-suited for the job. They are also able to incorporate a significant amount of innovation and flexibility to accommodate the diversity of contexts and circumstances that call upon the criminal justice system for a response. This encompasses circle sentencing and other tailored proceedings sometimes employed in Aboriginal communities; ${ }^{59}$ delayed dispositions to allow defendants to attend treatment

Ibid. at 13.

Ibid. at 166 .

Ibid. at 171 .

Criminal Code, supra note 19, s. 721.

Ibid., s. 722.

Ibid., s. 726.

These "alternative" approaches, many of which attempt to draw upon traditional First Nations' peacemaking practices, draw statutory support from s. 718.2(e) of the Criminal Code, ibid., and the seminal Supreme Court of Canada case of R. v. Gladue, [1999] 1 S.C.R. 688 [Gladue], which counsel courts to pay "particular attention” to the circumstances of Aboriginal offenders during sentencing. There is a significant body of scholarship on circle sentencing practices in Canada, much of it supportive of this approach's attempt to reconcile offender, victim, and community needs with the justice system's overarching structure and principles: see generally Ross Gordon Green, Justice in Aboriginal Communities: Sentencing Alternatives (Saskatoon: Purich, 1998), which also considers other initiatives, such as Elder panels and community advisory committees. Critical analyses of circle sentencing have also been made. For a feminist perspective that questions the practice’s ability to adequately safeguard victims of intimate violence, see Emma Cunliffe \& Angela Cameron, "Writing the Circle: Judicially Convened Sentencing Circles and the Textual Organization of Criminal Justice” (2007) 19 C.J.W.L. 1. For a Sto:lo scholar's critique of how such innovations cannot effectively address the colonialism and systemic injustices embedded in Western conceptions of justice, see Wenona Victor, Indigenous Justice: Clearing Space and Place for Indigenous Epistemologies (West Vancouver: National Centre for First Nations Governance, 2007) at 16. See also James (Sákéj) Youngblood Henderson, "Postcolonial 
programs before being sentenced; ${ }^{60}$ and provisions that enable courts to effectively extend their oversight over the course of an offender's community-based sentence, to monitor compliance, and make adjustments as deemed necessary. ${ }^{61}$ Sentencing hearings can even assume features of a contested trial: for example, when the Crown seeks to prove aggravating factors that are contested by the defence. ${ }^{62}$

This juncture of the mainstream criminal justice process, therefore, is in theory not merely amenable to, but actually designed for, the manifestation of certain restorative values. Referring back to Zehr's six questions, in court sentencing processes particularly address the criterion of dialogue, if not participatory decision-making per se: the law assumes that various voices and perspectives will be audibly raised in a hearing, and considered by the judicial authority. Although the premises of Canadian criminal justice are primarily retributive, and its force is coercive, hierarchical, and authoritative, the law also embeds the expectation that the justice that sentencing courts serve will be one of contextually calibrated, resonant expression. Risking the criticism of stretching the term, sentencing hearings are given a mandate not just of finding and delivering a fit sentence, but of contributing to the eventual restoration of an offender to a community of normative belonging. Sentencing courts are given to undertake this task through the communication (giving and receiving) of moral messages.

Before presenting my own observations of how restorative values are informing sentencing practices in a selection of courts in British Columbia, one final significant feature of court-based criminal justice must be considered: its overwhelming reliance on guilty pleas as the means by which its resolution processes are constituted. As with restorative justice processes, an offender's admission of wrongdoing predicates most of the work that sentencing courts undertake. Unlike what is required in most restorative justice programs, however, the admissions made in and accepted by mainstream courts are not necessarily reliable indicators of remorse or personal responsibility. In Part III, I explore what this ambiguity entails for the "restorativeness" of court-based resolutions.

\section{The Challenges of Plea-Based Criminal Justice}

The word "guilty" carries weight that a purely formal or legalistic framework cannot uphold. ${ }^{63}$ Judges, victims, and, indeed, all within the community of interest that a given crime creates, may reasonably seek to perceive, within or through the communication of a guilty plea, the redeeming seeds of remorse, accountability, and willingness to change. There exists a gap, however, between a legal order that defines and determines its expectations and impacts through a formalistic, procedural lens, and one that seeks to impart normative coherence upon its subject matter via more contextually rich interpretations. In light of the

Indigenous Legal Consciousness” (2002) 1 Indigenous L.J. 1.

60 As authorized by the Criminal Code, ibid., s. 720(2).

61 Ibid., s. 732.1(2)(b), which requires offenders serving probation orders to "appear before the court when required to do so by the court."

62 The Criminal Code, ibid., s. 724(3) provides for the establishment of facts considered relevant to the determination of a sentence. The standard of proof varies between a balance of probabilities for mitigating or neutral evidence, to proof beyond a reasonable doubt for aggravating factors. This difference, now codified, is a result of the Supreme Court's ruling in R. v. Gardiner, [1982] 2 S.C.R. 368.

63 See Fletcher, supra note 40 at 299-300. 
above review of law that seems to privilege the latter approach, this section critiques Canada's plea-based system of criminal charge resolutions as not exhibiting the commensurate clarity, openness, or participant engagement for sentencing hearings to discharge their restorative potential.

The plea is a significant - perhaps the significant - representation of the voice that courts give to and expect from defendants. We shall see that it communicates a very particular kind and content of information, which centrally affects the legal status of the speaker (defendant) and the structure and direction of the legal proceedings. In this respect, a defendant's voice, as expressed in the plea, has a clear and well-defined meaning. But such institutionally bestowed speech does not fully describe defendants' "voice," as it speaks or is silenced, heard, presumed, and interpreted in criminal proceedings. When the criminal defendant speaks, in a substantive moral sense, such speech is filtered through (and often walled up within) the institutional mechanism and institutional meaning of the plea. Confining my exploration to the major constituents of plea-based criminal justice (being resolution discussions, guilty pleas, and sentencing hearings), I attend to the audibility ideal and actual — of lay and professional participants' normative orientations towards "wrong” and “wrongdoer.” Meaningful moral communication between these actors in plea and sentencing proceedings is possible, I posit, to the extent that they are able and willing to share their normative stories in a common tongue. However, there is much, within and surrounding the articulation of the plea itself, that impedes the development and use of such a shared language. I consider some of these impediments below.

\section{A. A SNAPShOt OF British Columbia’s Criminal Courts: VOLUME OVERLOAD?}

All criminal prosecutions in British Columbia begin in the provincial court, and a vast majority — over 90 percent by the Court's own estimation ${ }^{64}$ — are ultimately disposed of at this level of court as well. On average, close to 70 percent of prosecutions in the province result in findings of guilt, ${ }^{65}$ while the largest percentage of others — nearly another 25 percent - are ended by a stay of proceedings. ${ }^{66}$ While it is clear from these statistics that only about 5 percent of prosecutions result in not guilty verdicts or other dispositions (such as outright withdrawals or peace bonds), it is less easy to quantify the proportion of guilty verdicts that are obtained by way of plea as opposed to a contested trial. Considerable anecdotal and experiential evidence, however, supports the conclusion that the overwhelming

64 Provincial Court of British Columbia, “About the Court,” online: Provincial Court of British Columbia <http://www.provincialcourt.bc.ca/aboutthecourt/index.html>.

65 The British Columbia Prosecution Service reported that 67.8 percent of prosecutions in 2009-2010 were disposed of by way of conviction: British Columbia Prosecution Service, Annual Report 2009/2010 (Victoria: Ministry of Attorney General, 2009), online: Ministry of Attorney General <http://www. ag.gov.bc.ca/prosecution-service/pdf/CJB-Annual-Report-2009-2010.pdf> at 14 .

A "stay" is (almost always) a Crown initiated request to the court for the prosecution to be discontinued. There are many possible reasons for such requests, principally including the Crown's recognition of insufficient evidence or other weaknesses that reduce the likelihood of conviction below an acceptable level. The cited figure for 2009-2010 was that 25.2 percent of all prosecutions resulted in a stay of proceedings: ibid. It is unclear, however whether this figure includes the many cases in which a defendant pleads guilty to only some of the charges in a multi-count prosecution, with the others being stayed. 
majority of these cases are resolved via guilty plea. ${ }^{67}$ The judgments and sanctions that provincial courts mete out, therefore, can fairly be said to be substantially predicated upon an offender's eventual admission of criminal culpability.

These admissions, further, are made in abundance. In the 2008-2009 fiscal year, 46,472 "total cases" were heard in adult criminal court in British Columbia. ${ }^{68}$ Other figures cite that an average of 85,000 reports to Crown counsel are forwarded from police to prosecutors in the province every year, which encompass approximately 92,000 accused persons and 165,000 criminal charges. ${ }^{69}$ The Provincial Court of British Columbia reports hearing an average of 100,000 adult criminal cases each year. ${ }^{70}$ More specifically, a 2006 survey of judges in British Columbia reported that judges individually conduct an average of 55 sentencing hearings each month. ${ }^{71}$ These findings reflect commensurate burdens on Crown and defence counsel to "get through" lengthy court lists. ${ }^{72}$

It would seem reasonable to conclude, from these statistics, that British Columbia's courtrooms can be very busy, time pressured places, which afford little room for the comprehensive, communicative engagement of non-professional perspectives. ${ }^{73}$ These pressures, of course, cannot be discounted as a principal reason why criminal courts are not more solicitous of the values and voices of lay participants. ${ }^{74}$ Some observers, however, have argued that other factors are equally, if not more, responsible for the justice system's shortcomings in this regard.

Joseph Di Luca, “Expedient McJustice or Principled Alternative Dispute Resolution? A Review of Plea Bargaining in Canada” (2005) 50 Crim L.Q. 14 at 15, quotes a figure of 80 percent in the Ontario context; Justice Gilles Renaud, in the introduction to his text Speaking to Sentence: A Practical Guide (Toronto: Thomson Carswell, 2004) at vii, estimates that " $95 \%$ of all criminal accusations result in a guilty plea of some kind."

Statistics Canada, "Cases in adult criminal court, by province and territory (British Columbia 2006/2007)," online: Statistics Canada <http://www40.statcan.gc.ca/101/cst01/legal19k-eng.htm>. “Total cases" comprises both Criminal Code offences (approximately 87 percent of this total) as well as other federal statute-based prosecutions, such as those conducted under the auspices of the Controlled Drugs and Substances Act, S.C. 1996, c. 19.

Brian Rendell, Ensuring an Effective Criminal Justice Response to Violence Against Women (Victoria: Ministry of Attorney General, 2009) at 4, online: International Centre for Criminal Law Reform and Criminal Justice Policy <http://www.icclr.law.ubc.ca/files/VAW/04\%20Brian\%20Rendell\%20VAW $\% 20$ presentation.pdf $>$. These figures likely comprise youth as well as adult files. Provincial Court of British Columbia, 2008-2009 Annual Report (Victoria: Office of the Chief Judge of the Provincial Court of British Columbia, 2009) at 11, online: Provincial Court of British Columbia $<$ http://www.provincialcourt.bc.ca/downloads/pdf/annualreport2008-2009.pdf>.

71 Justice Canada, Victim Impact Statements at Sentencing: Judicial Experiences and Perceptions by Julian V. Roberts \& Allen Edgar (Ottawa: Department of Justice Canada, 2006) at 1.

72 It is important to acknowledge that there is much variation in the volume of caseloads, in terms of quantity, type, and context. Considering only absolute numbers, this variation can range from very high volume urban centres to circuit courts that visit small communities only a few times per year.

73 See e.g. Main Street Criminal Procedure Committee, Report on Backlog in Vancouver Adult Criminal Court (Victoria: Office of the Chief Judge of the Provincial Court of British Columbia, 2005), online: Provincial Court of British Columbia <http://www.provincialcourt.bc.ca/downloads/pdf/Main StreetCriminalProcedureCommitteeReportonBacklog.pdf > .

74 See Brian A. Grosman, "Conflict and Compromise in the Criminal Courts: New Directions in Legal Research" (1969) 11 Crim. L.Q. 292 at 298. See also Milton Heumann, "Back to the Future: The Centrality of Plea Bargaining in the Criminal Justice System” (2003) 18 C.J.L.S. 133 at 136, citing George Fisher, Plea Bargaining's Triumph: A History of Plea Bargaining in America (Stanford: Stanford University Press, 2003). 


\section{B. The Court System’s Procedural Sanctions}

Malcolm Feeley's study of American plea courts, while conducted over 30 years ago, provides considerable insight into a problem that endures across jurisdictions. ${ }^{75}$ He disputes the common contentions that heavy caseloads, ${ }^{76}$ bureaucracy, ${ }^{77}$ a lack of skilled personnel, ${ }^{78}$ and/or pervasive plea bargaining ${ }^{79}$ "add up to a complete account of what shapes the decision process." ${ }^{80}$ As an alternative to the dichotomous "due process" ${ }^{\text {"11 }}$ and "plea bargain" ${ }^{22}$ models for explaining the brand of "justice" that courts privilege, both of which focus on outcomes, Feeley posits that an analysis of the process itself, from arrest through to disposition, tells us more about how the criminal justice system punishes defendants. This is a model that accords greater determinative weight to the implicit, systemic burdens and coercions placed upon accused persons than the explicit judgments and sentences that officially describe the justice that courts mete out. Feeley does not suggest that normative assessments are not being made in criminal law processes, only that they cannot be easily discerned either through official rationales or in the "noisy exchanges and rushed judgments" that characterize most plea and sentencing proceedings. ${ }^{83}$ He recognizes that "law is above all, a normative ordering. It gives expression to deeply felt sentiments within a society. Courts are staffed by representatives of this society, and what they do is in part a function of their own sense of justice." ${ }^{84} \mathrm{He}$ suggests, however, that “[ $\mathrm{t}] \mathrm{o}$ the extent that ... 'by-product' costs of the pretrial process loom large in the minds of the accused, courts are not and cannot be what they claim they are, for these costs shift the locus of sanctioning away from the formal stages of adjudication and sentencing onto the process itself." 85

Prison sentences are dwarfed by pretrial detention, fines, the costs of mounting a defence, or lost wages; and substantive crimes are overshadowed by an accumulation of charges for breaching bail conditions or missing court. ${ }^{86}$ In this unfocused, uncertain environment, decisions about what a particular defendant deserves are made in the colloquial barter between prosecutors and defence lawyers. These interlocutors assess a spectrum of factors (some so complex and subtle as to be invisible even to the ones employing them ${ }^{87}$ ) to arrive at a case's "worth.” This bartering, Feeley suggests, encompasses multiple conceptions of

Malcolm M. Feeley, The Process is the Punishment: Handling Cases in a Lower Criminal Court (New York: Russell Sage Foundation, 1979).

Ibid. at 12. He suggests that courts actually "organize their work so that they must operate at a frantic pace" [emphasis in original].

Ibid. at 12-13. Criminal courts, Feeley states, do not exhibit the central features of bureaucratic systems, being characterized by discretion, lacking strict hierarchies, and more "marketplace" than "assemblyline."

Ibid. at 14. He finds no evidence that more or "better” professionals lead to improvements in regards to the considered engagement of lay participants.

Ibid. at 12-14. The adversarial system, Feeley suggests, has never been fully operative, and people plead guilty for many reasons, including as a result of "losing” legal gambits in the pretrial process. Ibid. at 11-12.

Ibid. at 26-27. This model privileges procedural protections and assumes a "win/loss” mentality focused primarily on formal end results, but Feeley suggests that, in practice, strict results are not the overriding concern of either the prosecution or accused.

Ibid. at 27-28. This is a narrower variant of Packer's crime control model. Feeley acknowledges that plea bargaining benefits both parties with certainty, efficiency, and cost reductions, but, as mentioned above, questions whether it provides the best account of a court system's normative ordering.

Ibid. at 8.

Ibid. at 15.

Ibid.

Ibid. at 30.

Ibid. at 124-25. 
substantive justice: the adjudication of the act itself, the settlement of disputes, and a consideration of the actor, which tempers abstract principles with an eye to how they impact real persons and situations. ${ }^{88}$ Further, since the "theoretical exposure" ${ }^{89}$ (that is, maximum sentence) of most crimes is much harsher than what a defendant is realistically facing, defendants are easily convinced that their pleas represent "good deals." This affords defendants a sense of partial victory, and gives their representatives a chance to show their usefulness. $^{90}$

All of the factors weighed in such informal bartering processes are, of course, amenable to being aired in the formal, public forum of sentencing courts. The normative force and even relevance of this official apparatus, however, is exhausted by the explicit and implicit sanctions and trade-offs already made in the pretrial process. ${ }^{91}$ Feeley contends that this happens as a function both of the instrumental pressures borne by defendants, and the influence of professionals who render proceedings both technical and routine. It also occurs irrespective of caseload pressures. As he found in a comparative assessment of high volume and low volume courts, the basic tasks of both courts "are handled in the same rapid and perfunctory manner." 92 It is not volume, therefore, that erodes the criminal law's moral authority and expressive aspirations, but the "law-less" informal sanctions and unsupervised discretion that Feeley observed in both contexts. Although, he asserts, appropriate results may well be reached in individual cases, the justice system itself is indelibly weakened by the potency of pretrial coercions. ${ }^{93}$

\section{The Contorting Cultures of Courts}

Other pointed critiques have been advanced to explain the criminal justice system's failure to adequately function as a site for the communicative moral ordering of wrongs and wrongdoers. These include analyses which hold that the very culture of the law and legal professionals is responsible for impeding and devaluing the (moral) perspectives of lay participants. The influence of lawyers in producing efficient, disciplined guilty pleas has been a subject of critique and discussion for decades. Abraham Blumberg famously assailed defence counsel for contributing to the "confidence game" he observed playing out in an American jurisdiction in the 1960s. Guilty pleas, he contended, were engineered by lawyers who sacrificed "ideological and professional commitments" to clients in favour of maintaining self-interested relationships with other actors in the institutional structure. ${ }^{94}$ This, perhaps the most far-reaching condemnation of defence counsel as “double agent[s]" in an environment of coerced resolutions and hollow due process protections, ${ }^{95}$ was reassessed by

Ibid. at 22-24. This "equitable" assessment is reflected in the high number of stayed or withdrawn charges, especially in cases where it is accepted that the appropriate penalty has already been paid (at 274).

Ibid. at 190 .

Ibid. at 190-92.

Ibid. at 275 .

Ibid. at 260 .

Ibid. at 289.

Abraham S. Blumberg, "The Practice of Law as Confidence Game: Organizational Cooptation of a Profession” (1967) 1:2 Law \& Soc’y Rev. 15 at 19.

Ibid. at 31. See also Andrew E. Taslitz, "The Guilty Plea State” (2008) 23:3 A.B.A. Criminal J. 4, for a less incendiary updating of this argument. 
Debra Emmelman in her study of public defenders in California. ${ }^{96}$ The lawyers that she observed, unlike those under Blumberg's gaze, were sincerely motivated to advocate on behalf of their indigent clients. Instead, they were constrained, in the process of advising and representing those pleading guilty, by a cultural environment that frowned not merely on crime, but on clients' assumptions, impressions, world views, and interpretations. ${ }^{97}$ This, Emmelman concludes, was the main reason why the lawyers in her study tended to prefer plea bargained outcomes and strict "information control” during sentencing hearings, rather than allow their clients to speak freely. This approach was simply the best way to shepherd defendants through a hostile normative order that pejoratively assessed not only their alleged criminal conduct, but their very character and world view. ${ }^{98}$ The clear implication, from both Blumberg and Emmelman's studies, is that there is little meaningful chance for defendants to effectively address the system's interpretations of who they were and what they had done. Defendants in these settings are thus unable either to acknowledge, resist, or offer an alternative understanding of the moral valuations that implicitly and explicitly occur in the course of their cases.

\section{The Fraught Nature of the Plea Itself}

Despite, or because of, its near ubiquity, the guilty plea has not attracted a great deal of scholarly focus. Oonagh Fitzgerald's 1990 analysis of the plea's status and use in Canada stands as the leading academic text upon the subject. ${ }^{99}$ Her work continues to present a challenging critique of how Canada's law and justice systems have misused a most important mechanism. Fitzgerald argues that, despite what the law may officially expect, overt and covert coercions embedded in the court process undermine the reliability of the guilty plea as a "free" admission of guilt. Indeed, she states, "[f]ew guilty pleas could be described as entirely voluntary, given that nearly every guilty plea must be influenced to some extent by the hope of gaining a sentencing advantage."100 This situation, for Fitzgerald, is to some extent unavoidable in a system that holds out the expectation of mitigated punishment in exchange for acceptances of responsibility. ${ }^{101}$ For her, however, the plea's professional mediators, most pointedly defence counsel and judges, bear both the ability and onus to minimize the dangers this situation creates.

In keeping with Canada's express commitment to certainty in convictions, a plea of guilt is not legally valid until accepted by the court. It will be set aside if a judge determines that it was not made voluntarily or is not an unequivocal acceptance of the essential elements of the charge. A guilty plea is also liable to be refused or vacated if it is established that the accused does not adequately understand its nature and consequences, including that any sentencing agreement between the Crown and defence is not binding on the court. ${ }^{102}$ Yet despite this exacting standard, guilty pleas are the predominant means of resolving cases.

Debra S. Emmelman, Justice for the Poor: A Study of Criminal Defense Work (Burlington Vt.: Ashgate, 2003).

Ibid. at 37.

Ibid. at 103.

Oonagh E. Fitzgerald, The Guilty Plea and Summary Justice (Toronto: Carswell, 1990).

Ibid. at 138 [footnote omitted].

I discuss the status and rationales for this "plea discount" in Part III.E, below.

Criminal Code, supra note 19, s. 606(1.1). See also Don Stuart, Ronald J. Delisle \& Tim Quigley, eds., Learning Canadian Criminal Procedure, 9th ed. (Toronto: Thompson Carswell, 2008) at 715. 
Although not grounded in (or, indeed, countenanced by) Canada's textual legal framework of statutes and jurisprudence, the law, as Fitzgerald has argued, has evolved an implicit structure of pressures and enticements that exerts powerful influence on accused persons to plead guilty.

While for some the decision to plead guilty may be substantially driven by remorse, and for others the same decision may be motivated by entirely instrumental reasons, a veil is cast over this spectrum of normative rationales by the plea's function as a means of achieving systemic efficiency. Without concerted effort on the part of the parties and/or the process, the presence and range of moral orientations that are enveloped in guilty pleas tend to remain muddled and uncertain. It can be argued, of course, that this uncertainty has its own instrumental purpose: the justice system simultaneously benefits from the procedural efficiencies that guilty pleas produce, while also mining normative legitimacy from pleas' ostensible status as admissions of moral responsibility. It is, of course, impossible to concretely prove such a criticism. Some clues in this regard, however, may be evidenced by the way in which pleas are commonly produced in a plea-based system. This implicates the pervasive practice of plea bargaining.

\section{E. THE ENDURING INFLUENCE OF NEGOTIATED RESOLUTIONS}

In a system of justice that is founded on the presumption of innocence and proof beyond a reasonable doubt, but which must afford these principles to legally represented defendants, ${ }^{103}$ who appear before judges willing to hold the prosecuting state accountable for its promises, ${ }^{104}$ trials must necessarily be rare. Guilty pleas, without coincidence, are the most common procedural means by which criminal prosecutions are disposed. There is also anecdotal evidence that a negotiation practice (known in official parlance as "resolution discussions," and more colloquially as “plea bargaining”) is responsible for assuring both the quantum and the substantive content of "guilty plea justice" that has become so widespread in Canada and many other jurisdictions. ${ }^{105}$

Plea bargaining in Canada is a somewhat ambiguous, poorly bordered concept, which encompasses everything from informal hallway conversations between counsel to prearranged meetings mediated by a judge. Indeed, the term itself has proven controversial, with both proponents and detractors focusing on insinuations of commodified, bartered justice to either condemn the practice or seek to rebrand it under the more innocuous (but no less ambiguous) banner of "resolution discussions." ${ }^{106}$ Irrespective of the appellation (I use them interchangeably here) or their respective insinuations, it is clear that some manner of pre-plea

Due to cutbacks in legal aid programs in many Canadian jurisdictions, legal representation is less comprehensively available than it has been in recent decades. Many indigent defendants charged with minor crimes must represent themselves if they wish to proceed to trial. In my experience as a practitioner, however, this has not resulted in substantially more contested trials, perhaps due to the fact that attractive resolution options are still being offered by prosecutors, defendants are intimidated by the prospect of self-representation, and/or duty counsel are made available to assist people in pleading guilty. 2003) at 32, who found that judges in pre-modern England sat "at the pleasure of the crown" and thus heavily favoured the prosecution. By contrast, contemporary Canadian judges are independent and sworn to uphold the fairness of the adversarial system. Di Luca, supra note 67 at 15 . 
negotiation between justice professionals is an entrenched feature of Canadian criminal justice, as it arguably has been for a long time. ${ }^{107}$ There is a suggestion, moreover, that despite official administrative attempts to recuperate and recast plea bargaining "as a mandatory and desirable component of our modern justice system," it "remains at its most basic a process whereby an accused person 'bargains' with the prosecution in the hope of receiving the most favourable treatment possible. Concessions by accused, most notably concessions of guilt, are the currency with which the favourable treatment is purchased."108

It is tempting to deduce from this view, which is not seriously refuted in the literature, that plea bargained cases - namely those in which the charges, facts, and/or sentencing recommendations have been agreed upon beforehand by counsel - drain the formal sentencing hearing of moral relevance, resonance, and authority, to say nothing of its ability to reflect restorative values. This is true, I argue, to the extent that Crown counsel are motivated to "resolve" cases solely according to the instrumental objectives of efficiency and certainty, defendants accept or reject offers on the basis of a similarly instrumental costbenefit analysis of expected outcomes, and victims are given little or no say in negotiations. As Fitzgerald baldly states, “[lawyers'] motives for agreeing on the guilty plea may be quite inimical to concerns of justice."

This criticism is resisted, or at least reinterpreted, by those professionals most responsible for engineering negotiated outcomes. Mary Dickie, a Crown attorney in Ontario who has written about the Crown's role in this regard, highlights the flexibility that resolution discussions can promote, in terms of time but also "flexibility in approach, such as allowing victims to be present for parts of the meeting ... where there is a need for an apology that is appropriate for the case as part of the resolution." ${ }^{\text {"10 }}$ Dickie also stresses that proposed resolutions cannot infringe the fundamental sentencing principle of proportionality as to the gravity of the offence and degree of responsibility of the offender. ${ }^{111}$ This perspective is explicitly reflected in provincial guidelines for the use of prosecutorial discretion in this area. $^{112}$

Commentators from the defence perspective have tended to take a somewhat more cynical, instrumentalist view of why negotiated pleas remain so important to the criminal justice system's functioning. Ontario lawyer Joseph Di Luca agrees that efficiency and certainty are certainly basic motivators for defendants to enter into resolution discussions, but suggests that this does not often happen in a free and flexible environment. ${ }^{113}$ In Di Luca's view, a context of widespread pretrial detention, overcharging, and the gap (whether actual or perceived) between the punishments that defendants expect to receive after a trial versus a

See Heumann, supra note 74 at 135, for a discussion of Fisher's historical findings.

Di Luca, supra note 67 at 18.

Supra note 99 at 215.

Mary Lou Dickie, "Through the Looking Glass - Ethical Responsibilities of the Crown in Resolution Discussions in Ontario” (2005) 50 Crim. L.Q. 128 at 136. The relevant policy framework is substantially the same in Ontario and British Columbia.

Ibid. at 139 .

See e.g. British Columbia Ministry of Attorney General, Crown Counsel Policy Manual: Resolution Discussions and Stays of Proceedings (Victoria: Ministry of Attorney General, 2009) at 1-2, online: Ministry of Attorney General <http://www.ag.gov.bc.ca/prosecution-service/policy-man/pdf/RES1ResolutionDiscns_SOPs-2Oct 2009.pdf> [Crown Counsel Policy Manual].

Supra note 67. 
guilty plea create coercive conditions that bury criminal law's substantive values and procedural promises. In extreme cases, he suggests, these forces can even push those who are innocent to plead guilty simply to end their ordeals. ${ }^{114}$ Although these types of wrongful convictions are perhaps the least illuminated of the justice system's miscarriages, due to the fact that guilty plea-based outcomes are rarely appealed, the findings of the recent Inquiry into Pediatric Forensic Pathology in Ontario, ${ }^{115}$ as well as the Ontario Court of Appeal's decision in $R v$. Hanemaayer, ${ }^{116}$ illustrate that such miscarriages do occur. In minor or "routine" cases, this problem may be even more acute, given that, as Feeley observes, the costs of proceeding through the system can outstrip the official sanction of a negotiated or plea-based outcome.

The majority of defendants whose pleas are negotiated are directly represented at resolution discussions ${ }^{117}$ by a legal professional who is mandated to act in their best interests. This orientation is commonly applied in a mercantile fashion, with defendants presumed to adopt a rational bargaining position according to the attractiveness of plea offers and the anticipated risk of proceeding to trial. Such a presumption, while a seemingly reasonable heuristic for defence counsel to adopt in relation to most of their clients, must be adapted to the practical as well as normative considerations active in each particular context.

Some of the practical factors have already been mentioned. Much work has been done, for example, on the effect that pretrial detention has on a person's likelihood of pleading guilty. ${ }^{118}$ Studies have noted that while the prison population itself has remained relatively stable, ${ }^{119}$ the detention of persons before trial has risen over the past decade to include roughly half of all those in provincial institutions. ${ }^{120}$ Simply put, persons whose freedom the law has forfeited before finding them guilty are much less inclined to exercise the due process rights that are ostensibly theirs. The pressure to settle, often in exchange for release, thus threatens to indelibly colour plea negotiations and, consequently, sentencing hearings. Defendants who are, understandably, motivated to secure their release may agree to plead guilty irrespective of their normative orientation towards the actual offence or negotiated outcome, and professional representatives may, also understandably, end up advising and encouraging cost-benefit decision-making in spite of policies and principles that justify plea bargaining as facilitating substantively just outcomes. The instrumentalism of this process also "imprints upon [accused persons] a conception of criminal prosecution as a system

Ibid. at 37-38.

(Toronto: Ontario Ministry of Attorney General, 2008), online: Attorney General for Ontario <http:/l www.attorneygeneral.jus.gov.on.ca/inquiries/goudge/index.html>. In nine of the 14 cases reviewed by the Inquiry in which incorrect pathologist conclusions resulted in wrongful convictions, the accused had pleaded guilty. 2008 ONCA 580, 239 O.A.C. 241.

Unrepresented accused persons may, of course, enter into resolution discussions with prosecutors on their own behalf, but such meetings are actively discouraged by most Crown counsel. The British Columbia Crown Counsel Policy Manual, for its part, urges prosecutors to "exercise caution" in this area, and encourage defendants to seek legal assistance: supra note 112 at 3.

See e.g. Gail Kellough \& Scot Wortley, "Remand for Plea: Bail Decisions and Plea Bargaining as Commensurate Decisions” (2002) 42 Brit. J. Crim. 186. and federal programs (British Columbia)," online: Statistics Ca (1//)www40.statcan.gc.ca/101/ cst01/legal31l-eng.htm>.

120 See Cheryl Marie Webster, Anthony N. Doob \& Nicole M. Myers, “The Parable of Ms Baker: Understanding Pre-Trial Detention in Canada” (2009) 21 Current Issues in Criminal Justice 79 at 82. 
which is subject to manipulation by those experienced at the game to the exclusion of those who are not." 121

Finally, there is the potentially detrimental influence of defendants' representatives themselves. As Fitzgerald alleges in her critique of plea-based criminal justice, “[g]iven the fiduciary relationship between defence counsel and client, the pressures exerted by counsel may be the greatest threat to an accused's freedom of choice in pleading and the most important influence in prompting negotiated pleas of guilty."122

Ultimately, there is little argument that defence counsel must fearlessly advocate on behalf of their clients' legal interests throughout their representation. This is most clearly evident in a contested trial and, as we have seen, also applies, though in a much murkier context, in plea negotiations that attempt to secure viable deals. To the extent that a comprehensive agreement is reached with the prosecutor, a defence lawyer's duties at the sentencing hearing are usually confined to a straightforward sales pitch, in which a client's involvement will not likely be required or encouraged beyond rote acknowledgments. As Feeley's account of the implicit normative ordering that occurs throughout the legal process acknowledges, in cases such as these there is little left for either lay participants or judges to do, and the sentencing hearing itself becomes no more than a hollow, pro forma ritual with a foreordained conclusion. Not infrequently, however, and even within those cases that have apparently been decided beforehand, it becomes a matter of a client's "best interests" that they be viewed by the presiding judge in the most sympathetic light possible.

For any (including judges themselves) who privilege the law's concern for substantive, justly informed decision-making at sentencing, the characterization of judges as mere figureheads must therefore be gravely considered, and stridently resisted. Fitzgerald, for example, strongly counsels against judges who passively accept the bona fides of a guilty plea without inquiring into its formation:

\footnotetext{
Because the guilty plea process is so susceptible to pressures that detract from the acceptability of the guilty plea, the conscientious performance of the trial judge's supervisory role is crucial. Unless the trial judge makes inquiry into the circumstances of the plea and any plea bargain, there is no reason to assume that the guilty plea is voluntary, intelligent and accurate and therefore no basis upon which to accept it as a legitimate means of resolving a criminal matter. ${ }^{123}$
}

Notwithstanding the passivity that Fitzgerald rightly critiques, however, there are indications that judges are indeed interested, and motivated, in taking a much more active

121 Grosman, supra note 74 at 301.

$122 \quad$ Supra note 99 at 146 [footnote omitted].

123 Ibid. at 168-69. The kind of inquiry that Fitzgerald endorses is also now mandated by s. 606(1.1) of the Criminal Code, supra note 19, which states that

[a] court may accept a plea of guilty only if it is satisfied that the accused

(a) is making the plea voluntarily; and

(b) understands

(i) that the plea is an admission of the essential elements of the offence,

(ii) the nature and consequences of the plea, and

(iii) that the court is not bound by any agreement made between the accused and the prosecutor.

The failure of a court to make such inquiries, however, does not affect the plea's validity (s. 606(1.2)). 
role in ascertaining and shaping the normative features of the justice process. As we have observed, these normative forces withstand and coexist with the instrumental pressures and function of plea and sentencing processes.

Gauging an offender's moral orientation towards their offence is a key aspect of this role. A judge's perception of remorse, as Richard Weisman has argued, including its presence or absence but also its authenticity and depth, plays strongly into the "moral dichotomization of those who have been found to be culpable." 124 This, in turn, makes a difference to their treatment:

Wrongdoers who are regarded as remorseful are viewed as more worthy of mercy, safer for re-inclusion into the community, and more similar to their law-abiding neighbors than those who have not shown remorse or whose expressions of remorse are judged as not credible. ${ }^{125}$

Weisman recognizes the distorting effects that the legal process can have on this discernment. Convincing moral performances matter, of course, but they are made "in a context of suspicion ... affected by their proximity to law’s own coerciveness."126 More than an apology, therefore, and much more than the simple act of pleading guilty, is required from defendants to prove to judges that their manifest remorse is worth a reduced punishment. A guilty plea's instrumental efficiency, here, though privileged in some of the literature above as a valid, distinct rationale for mitigating punishment, is the remorseful offender's enemy, for it taints the authenticity of their feelings. As Weisman shows, judges are concerned with reading into defendants' non-verbal "body glosses” and “indicia of ... personal transformation" in determining whether their more formal expressions of accountability most often a plea and apology — are genuine and credible. ${ }^{127}$ While defence counsel may engineer, represent, and manage some of these signs, their involvement can also weaken or counteract the "true feeling" that a sentencing judge is trying to discern, and a client is trying (or trying not) to convey. Weisman locates considerable nuance and paradox in offenders' "messaging" of remorse in criminal court. It is here that defendants are expected to fully acknowledge and offer no excuses for their wrong, so that they may be seen as having transcended their transgression, and consequently be appropriate recipients of mercy/mitigation. ${ }^{128}$ While the question of remorse offers arguably the most important and meaningful opportunity for courts and offenders to communicate with each other (defendants, for example, need to know the precise bases upon which they are being judged, in order to respond to the normative assessments to which they are subject), the stories that judges and defendants tell each other are circumscribed by the pressures and compromises leading up to this denouement. Although judges, who may not be involved in, or responsible for, the legal and factual bargaining that often becomes the version of "what happened" that is brought into court, do, according to Weisman, sincerely try to discern an offender's "true feeling” about their wrong, their ability to effectively assess such qualities are stunted and strained by the narrative enclosures within which sentencing hearings commonly operate. Community” (2009) 18 Soc. \& Leg. Stud. 47 at 49.

Ibid.

Ibid. at 50-51 [footnote omitted].

Ibid. at 51-52 [citation omitted].

Ibid. at 52-54. 
Further, as Weisman notes, in this context, it is not so much whether remorse is actually felt by an offender, it is whether (and how) it is recognized according to the "'feeling rules' of the community," ${ }^{129}$ which a judge is implicitly tasked with applying. These rules, in his view, require an appropriate measure of felt suffering (for having done wrong) and surrender to the moral authority of the court, untainted by any suggestion of strategic posturing. There must be neither excessive nor insufficient emotion here, and no stray strand of feeling can be allowed to detract from the performance. The courtroom display of remorse, it seems, is executable only by virtuosos or the utterly guileless. It is small wonder that, in practice, lawyers tend to counsel the less risky option of silence or short utterances of regret, lest their clients' feelings — express and/or judicially interpreted — run afoul of the rules that, according to Weisman's argument, exert informal but forceful influence over how cases are ultimately discerned and decided.

\section{F. CONCLUSION}

As we have seen thus far, there are both opportunities and impediments to substantive, sustained dialogue among participants at the plea and sentencing stage of mainstream criminal justice proceedings. The opportunities, in keeping with a theory of criminal law as fundamentally interested in proportionately apportioning blame for this offence to this offender, are substantially found in the Criminal Code's provisioning for the balanced presentation of perspectives. These provisions include allocution, victim impact statements, and mediated representations from the community and the wrongdoer. Such opportunities are further endorsed and expanded by some of the literature that focuses on the flexibility of pre-plea negotiation processes, and the potential that lawyers and judges may have to therapeutically support the normative engagement of lay participants.

Most of the analyses of how the mainstream justice process operates that have been considered in this section, however, speak strongly of the abiding and widespread impediments to this aspiration. These critiques are found throughout systems and across jurisdictions. The moral ordering that is, necessarily, done in the course of a criminal justice process, these analyses suggest, mostly happens in the dim light of bargained outcomes and the poorly regulated punishments incurred in the procedural burdens that defendants bear prior to, and irrespective of, their adjudged guilt. For these observers, although judges are officially empowered, and often motivated, to inquire into the underlying "harms, needs, and causes” of a particular case, ${ }^{130}$ their efforts are hampered and often trumped both by competing instrumental pressures and other, less measurable interferences to the restorative viability of sentencing hearings.

This section identified the major obstacles to dialogic norm sharing in a system that, arguably, purports and aspires to build its assessments and ultimate authority upon such a foundation. I have explored these obstacles by way of guilty pleas, in part due to this mechanism's sheer predominance in a system of plea-based criminal justice, but also to inquire whether guilty pleas provide any nurturance to normative dialogue in sentencing hearings. I found that the preponderance of the literature suggests that guilty pleas, to the 
extent that they can be validly characterized as strictly instrumental admissions, chiselled by coercive forces and managed by professional representatives, tend to stifle moral engagement, and thus the court process' potential restorativeness, more than they sustain it.

It is evident that there are multiple, interwoven reasons why guilty pleas do not, by and large, further substantive communication in sentencing hearings, and why these hearings cannot, thereby, discern or articulate contextually calibrated, truly resonant dispositions. The literature that I have canvassed advances a corresponding braid of explanations and prescriptions, attuned to each observer's focus and location. Theory, existing empirical studies, and statistics all suggest that the guilty plea is a pervasive but problematic mechanism for ascribing moral culpability. This evidence, moreover, points towards guilty pleas as acting more as obstacles than invitations when it comes to furthering moral communication and dialogue in sentencing hearings. In this article's final section, three sentencing courts in British Columbia are observed to discern how each is furthering any of Zehr's criteria of restorativeness in its day-to-day operations in a plea-based system. In light of the foregoing discussion, I cannot presume that all or, indeed, most of Zehr's six questions can be affirmatively answered by any court operating in the mainstream justice system; there are simply too many countervailing factors and concerns impinging on the restorative potential of any forum that functions in such a formally retributive, plea-based environment. Notwithstanding this important caveat, the following research reveals that there are some models, and some motivated participants, that are breathing some restorative life into sentencing courts.

\section{The Restorative Profiles of Three Criminal Courts}

For all their insufficiencies, criminal courts, in particular those accepting pleas and passing sentences, continue to function as official forums for the resolution of wrongs, and it is important to ask how they are actually doing in this regard. The courts that I have selected for this empirical study are the Provincial Plea Court at 222 Main Street, Vancouver (Court 102), the Downtown Community Court at 211 Gore Street, Vancouver (Community Court), and First Nations Court in New Westminster (First Nations Court). These three forums (collectively, the study courts) afford glimpses into the variety of contexts within which courts in British Columbia operate. Court 102 offers an urban, high volume setting for observing the "orthodox" performance of plea and sentencing proceedings. Community Court, located only steps away in the same downtown neighbourhood, handles similar crimes and clientele, but incorporates a more collaborative and problem solving approach to its cases. ${ }^{131}$ First Nations Court, based in New Westminster, is a unique court for Aboriginal offenders in the Lower Mainland. It conducts the same proceedings as any criminal court, but operates with a much smaller caseload than the above two courts, and adopts an approach designed to redress the disadvantages experienced by Aboriginals in the mainstream justice system.

131 Downtown Community Court, Information for Accused Persons: How the Downtown Community Court Works (Vancouver: Provincial Court of British Columbia, 2008), online: Criminal Justice Reform Secretariat <http://www.criminaljusticereform.gov.bc.ca/en/shared/downloads/information_for_ accused.pdf $>$. 
The study courts share important common features. All three are provincial courts in the province of British Columbia, presided over by provincially appointed judges with identical powers, sworn mandates, and responsibilities. All, moreover, apply the provisions of the Criminal Code to a roughly similar spectrum of criminal offences. Finally, all of the study courts are exclusively plea-based, meaning that they do not conduct trials. All 44 of the sentencing hearings that I observed across the three courts followed a guilty plea.

As introduced above, each study court is also distinct from the others, in terms of its workflow, approach, and situation within a given community. This combination of commonality and difference frames the underlying research question that this section sets out to address, which is how sentencing courts within the mainstream criminal justice system are manifesting restorative values.

Before delving into my findings, however, I must note at the outset that none of the three courts that I selected were observed to practice in a victim-centred way. Despite the formal opportunities for victim involvement that are embedded in the governing law, the participation of these important stakeholders was virtually non-existent: out of the 15 hearings I observed that concerned an identifiable, personal (that is, not institutional or abstract) victim, only four of these evidenced any victim input into the sentencing process. Most of this input, moreover, was delivered through the submissions of Crown counsel; in none of the cases that I observed was the victim in attendance, and in only one case was a formal victim impact statement submitted to the judge. This pervasive reality puts an immediate damper on any argument for the comprehensive "restorativeness" of the courts considered below (and, arguably, for court-based criminal justice generally), at least according to all six of Zehr's criteria. My observations thus settled upon the communicativeness of these courts, vis-à-vis their ability to engage offenders, in particular.

I also concentrated specifically on the audibility of the moral themes of an offence's wrongness, as well as that of an offender's responsibility. These two interrelated themes, I hypothesized, are those most essential to a court's statutory obligation to impose contextually proportionate (retributive) sentences. The effective discernment and communication of these themes, I further reasoned, would arguably be important to any opportunities that a court could provide offenders for (restorative) reintegration into a community of shared meaning.

These considerations, admittedly, are but partial indicators of "restorativeness"; the axis that this research draws upon, and the markers that it plots, are thus not of a court's full restorative potential per se, but rather its ability to further one aspect thereof in a state-based system that is often seen as standing in direct opposition to restorative values and practices.

\section{A. COURT 102 At 222 MAIn Street, VANCOUVER}

\section{INTRODUCTION}

Court 102 is located on the ground floor of the Provincial Court building that occupies an entire block on the east side of Main Street in Vancouver's poorest neighbourhood. There is a police station across the street, and often a queue of people waits to be cleared through the metal detectors that guard the Court's entrance. Computer printouts stapled to a notice 
board in the foyer, and replicated outside each courtroom, alphabetically list the names of the accused whose cases will become that day's business. The sheet prepared for Court 102 is invariably incomplete; the surnames of those whose lawyers have brought them into the Court without advance warning are written in erasable ink on a whiteboard inside the Court itself, and are kept current by the sheriff in charge.

The whiteboard is affixed to the wall adjacent to a glass walled prisoner's box; the names that the sheriff writes and erases match the individuals who emerge from the cells downstairs to face the charges that have led to their detention. Bolted to the other wall is a television monitor, which often displays a prisoner who has chosen not to be brought downtown from the pretrial detention facility; the facilities in Court 102 allow sentencing hearings to be conducted via this closed circuit telecommunications system.

The television and the whiteboard are two of the most obvious signs of the efficiency and flexibility that this Court privileges. It has been physically designed to accommodate a large volume of daily cases, many of which are not completely planned or scheduled very far in advance of the appearance of a body in the dock or a visage on the screen. Persons who are not in custody also appear in Court 102, but my observations suggested that it is unique among the study courts in terms of the proportion of those who have been detained prior to sentencing. Not merely a majority, but almost three times the number of the offenders whose hearings I witnessed were in pre-sentence custody, compared with those who appeared for their hearings without shackles and an orange jumpsuit. Finally, Court 102 is a true plea court: all those who appear before this Court will have indicated, usually by way of their representative, that they wish to plead guilty to some or all of the charges against them.

Court 102 conducts significantly more sentencing hearings than the other courts in the observation study: in the seven hours that I spent observing its proceedings, over five visits in the winter and spring of 2009-2010, 22 such hearings were held. The actual average length of the sentencing hearings that I observed in Court 102 was 12 minutes. As a Crown counsel at the Court confirmed for me, this is a court meant for cases that can be completed in 20 minutes or less. He estimated that each day in Court 102, an average of ten to 12 criminal cases are brought to their formal conclusion.

In large part, therefore, Court 102 is a court of convenience for legal professionals, as, arguably, it is for the justice system itself. Nineteen of the 22 hearings that I observed involved an offender who was represented by counsel. Defence counsel, along with the prosecutor, are largely responsible for gauging which cases are appropriate for the Court. Many different lawyers spoke before the Court in the course of my observations, and most seemed fully cognizant of, and comfortable with, the volume and pace of proceedings. The Crown counsel who conducted the prosecutions during my visits usually entered in the morning with a large stack of briefs, and more would be handed to him as the day's list progressed. Cases were called in quick succession, and there were frequent whispered discussions between counsel who were waiting for their matters to be heard. Lawyers came and went through a side door of the courtroom that was restricted from public access. Sitting in the public gallery, which was separated from the professionals' benches by a low wooden wall, it was often difficult for me to hear what was being officially addressed up front. 
There were not often more than two or three other people on these public benches; sometimes the friend or relative of an offender sat in anticipation of seeing a familiar face, always unsure of when (and sometimes even if) it would emerge from the door leading down to the prisoners' cells. None were included as active participants in any of the hearings that I observed, and I did not notice the appearance of any victim or victim supporter in the eight cases that dealt with a crime against particular person(s) or their property.

Three different judges presided over Court 102 during the days I visited there. Each brought their own approach to its challenging demands, but all seemed more or less in tune with the efficiencies prioritized by other legal professionals and the Court's very design. Even within the same structure and context, however, different judicial personalities did contribute to different depths and kinds of engagement between the parties during the sentencing hearings that I observed. There was a particularly familiar rapport between certain professionals, while in other instances a judge would anticipate or cut a lawyer's submission short to offer their own interpretation of what was important in the case at hand, or to deliver a cursory conclusion. Sometimes a judge would address the offender directly when imposing the sentence, but others would issue monotone judgments, without looking up from the bench.

\section{DISCUSSION}

I chose to observe Court 102 for two main reasons. Primarily, as a high volume, pleabased setting, I (correctly) anticipated that it would yield the greatest number of sentencing hearings to include in this study. I was also interested in the content and quality of the hearings themselves: in light of my thesis that substantive normative communication is an important aspect of, even requisite to, a sentencing court's duty towards specific parties and the community at large, I wondered how a high volume plea-based court would incarnate this idea. In a sense, before even beginning my observations, I thought that Court 102 would present an extreme manifestation of some of the critiques of summary justice that were considered in the previous section: that it is explicitly designed to favour speedy resolutions, dominated by lawyers, dealing primarily with persons under the state's detention, and located in a neighbourhood marked as troubled. How, I asked upon first coming through its doors, could this forum discharge the obligations of open, morally referenced discernment and expression that a restorative or retributive approach to sentencing arguably requires?

My actual findings can be interpreted as both reinforcing and challenging my expectations about how an orthodox plea court functions. The following discussion examines some of the themes that I found most important to understanding the restorative values that Court 102 could be perceived as accommodating, as well as neglecting or rejecting.

\section{a. Most Hearings Featured Claims About a Crime’s Moral "Wrongness”}

A solid majority of the cases that I observed did feature audible claims or conclusions regarding the moral dimension of the criminal conduct that the Court was judging. In terms of this speech, professional and/or lay participants explicitly spoke to the moral proportionality (or wrongness) of the offence in 16 of 22 cases. Further, in five of these 16 cases, audible statements were made concerning the moral responsibility felt by an offender. 
On their own, of course, these figures say little about the depth or centrality of Court 102's restorative engagement with the persons and situations that come into its purview. They do, however, provide evidence that the theme of moral responsibility is commonly voiced in this environment, at least in numerical terms, even given the meagre conditions that Court 102 seemed to offer for its sustenance.

b. Commentary Directed to a Crime’s Moral Wrongness Primarily

Involved Representations of Proportionality, and Was

Primarily Voiced by Defence Lawyers

Beyond noting that articulations of moral responsibility were audible in a majority of the cases that I observed in this high volume plea court, I was interested in hearing who spoke, and on what topics. It is perhaps not surprising that defence counsel were the most common spokespersons in Court 102 . Defence counsel spoke regarding moral proportionality in 13 of the 16 cases where it was raised, compared to five instances by the judge, three by the prosecution, and three by the offender. It was apparent that in cases in which they were represented, most offenders were silent on the subject of moral proportionality; their lawyers made these submissions on their behalf.

In regards to their own moral responsibility, offenders spoke on the subject in three of the five cases where it was heard, in each instance offering statements of remorse. Judges commented upon this subject in two cases, and the defence in two as well. The Crown's voice was not heard on the subject. I note these findings as unsurprising because they reflect my presumption of which party is best placed to give voice to these two facets of wrongness and responsibility. As others have recognized, ${ }^{132}$ competent and motivated representatives, on both sides of the counsel table, can adequately speak to most of the factors relevant to a judicial discernment of moral proportionality (that is, the wrongness of a given crime). Furthermore, while judges cannot guarantee that offenders will be responsive to their admonishments or encouragements, they can at least communicate the acceptance or rejection of the factors of moral proportionality in an open court. As reflected in the above narratives, the statements concerning moral proportionality that I heard in Court 102 were almost invariably made by lawyers. These submissions required no participation of the offender directly. Because of the inherently intimate, subjective nature of an offender's orientation towards their conduct, however, offenders are personally implicated, either directly or indirectly, whenever this subject is discussed. I thus used representations upon this topic as a bellwether of offender engagement. The fact of its presence in a given hearing does not, of course, thereby establish an offender's meaningful inclusion in the justice a court conducts, just as its absence does not prove a lack of engagement. It is simply one measure - but, from an observer's perspective, one of the few that are accessible - of how courts and offenders are engaging with each other's normative perspectives, to the extent that they are interested in, and capable of, doing so. According to this measure, I observed Court 102 to be a place of rather shallow and infrequent communication.

132 See e.g. Kimberly A. Thomas, “Beyond Mitigation: Towards a Theory of Allocution” (2007) 75 Fordham L. Rev. 2641 at 2658. 
c. Conversations on the Themes of Wrongness and Responsibility

Tended to be Cursory, and Dominated by Professionals

I heard conversations on the above themes take place in eight of the hearings that I observed. Seven involved discussions of a crime's moral proportionality, while one concerned the offender's moral orientation towards their conduct. These conversations, such as they were, involved only two parties in every instance, in a number of configurations. The offender and judge featured in three, the Crown and defence in two, and the Crown and judge, defence and offender, and defence and judge in one each. I was particularly interested in the conversations between offender and judge, since these exchanges conceivably represented dialogues with the most restorative potential. With an occurrence rate of three in 22, the incidence of these conversations in Court 102 was not altogether encouraging given my hypothesis regarding their centrality to the criminal law's fundamental purpose. It is further worth noting that two of these three conversations featured unrepresented offenders; in 18 of the 19 hearings that I observed with defence counsel present, the offender did not engage in any dialogue with their sentencing judge.

d. Guilty Pleas Were Sometimes Treated as Criterion of Mitigation, But Not as Openings for Engagement Upon the Themes of Wrongness or Responsibility

Upon undertaking this study, I wondered if guilty pleas would be audibly interpreted, by judges, as worthy of consideration for either their instrumental or moral value. As was discussed above, one of the major critiques and rationales for the pervasive practice of plea bargaining is that it allows the justice system to more quickly dispose of cases without engaging the cumbersome repertoire of proofs and procedures that a trial requires. A plea's instrumental value, however (as compensated for by a discounted sentence), would seem to question, if not contradict, its use as a normative conveyance. Indeed, a solid majority of the hearings that I observed in Court 102 skirted this issue entirely by not referring to the significance, timing, or circumstances of the offender's plea at all. It was explicitly referred to in seven hearings. I observed that although the fact of a plea was accorded mitigating value in these instances, its performance added little if anything to an offender's normative engagement with the proceeding in which it was made.

On three of the occasions in which it was raised, a judge referred to the early entry of a guilty plea. In another, it was defence counsel who pointed out an offender's timely plea. In all of these cases, this representation supported mitigation of punishment, although it was always left unsaid whether or not credit was being given for instrumental efficiency or because it displayed evidence of the offender's quick flowering remorse. In another three hearings, somewhat clearer connections were drawn between a guilty plea and the offender's normative orientation. This link was made by the judge in two cases, who noted the plea in the same breath as the offender's adjudged remorse or acceptance of responsibility. In the third, it was the defence counsel who stated that his client "recognizes that something has to be done ... he has pled guilty," as an indication that the plea was more than a mere stratagem. The offender, however, did not speak to this point in any of the seven hearings. 
By neither explicitly repudiating nor openly accepting the notion that guilty pleas, in and of themselves, are worthy of consideration on either instrumental or moral terms, the hearings that I observed in Court 102 maintained the communicative ambiguity of this legal instrument. In a system characterized by broad discretion and partially submerged reasoning, this ambiguity may actually be useful to judges, if not to offenders who cannot be certain of how it will be interpreted or employed by a given judge in a given case. From my observations of the Court, the guilty plea retained its protean character, and was used to bolster arguments or decisions regarding sentence mitigation when deemed advisable by lawyers or judges. It was not, from my observer's point of view, a particularly incisive or expressive conduit of an offender's moral orientation. Court 102 required a guilty plea as a condition of hearing a given case; it did not require, expect, or, from the preponderance of judicial commentary that I observed, particularly concern itself with remorse. As mentioned in the introduction to the Court, Court 102 is a court of convenience for legal professionals, and privileges the efficiency that guilty pleas deliver. This approach is particularly for offenders who have been held in custody pending their conviction, but it may benefit lay participants as well. Court 102's concern for systemic efficiency, however, is mirrored in its tendency to summarily assess each individual case. Without a specific (instrumental) reason to explain or question the normative orientation behind a plea, therefore, it is unlikely that any such discussion would take place. For an offender, this reason can come in the form of an impending jail sentence. For a judge, it may come as part of a justificatory exercise for imposing a particular sentence.

e. The Offender's Past Tended to be More Influential in Determining

Sentences Than the Circumstances of Their Present Offending

The final feature that I present as necessary to an understanding of Court 102's operation is the reliance that I observed to be placed upon an offender's past, in contrast to the immediate circumstances of their present offending. In particular, representations in 19 of the 22 sentencing hearings that I observed in Court 102 focused on the existence and relevance of the offender's criminal record, as a consideration for the judge's determination of an appropriate sentence for the offence before the Court. While the judicial use of a person's prior criminal history as an aid in determining their degree of responsibility for a subsequent offence is standard practice in most sentencing courts, ${ }^{133}$ its employment in Court 102 was often the dominant, and sometimes the only, audible reference point for a sentence imposed.

\section{B. VANCOUVER's Downtown COMMUNiTy CoURT}

\section{INTRODUCTION}

Vancouver's newest, and most formally distinctive, provincial court is located just a few steps away from 222 Main Street, in the same building, in fact, that once held prisoners waiting for their cases to be heard there. Community Court was established in 2008 with the express aim of fostering a more "responsive," "connected," and "collaborative” problem solving approach to criminal offending, in particular that which arises from addiction, mental 
illness, and the related social dysfunctions that are found in such high incidence in the poor neighbourhood in which the Court operates. ${ }^{134}$

Given that it is located in the basement of a former detention centre, Community Court is a remarkably warm and attractive space. Children's colourful representations of "justice" hang in frames upon the wall, and the waiting area is adorned with a mural that has transformed white concrete into a legend laden forest, where giant sockeye swim through the aurora borealis, ancestors' faces blend in with evergreens, and someone scatters seeds into a mountain stream. It is an evocation of beauty that can be difficult to perceive on the hard streets just outside, but nonetheless seems quite intimately resonant of this community's memories and aspirations. The courtroom itself is wood panelled in bright ash and pine, and lit not with the fluorescent tubes that my eyes grew accustomed to in other courts, but with small and stylish halogen lamps suspended from the ceiling. Instead of wooden benches, the counsel and spectator benches are comfortably upholstered. There is, of course, the glassedin prisoners' box, the raised judicial dais, and the coat of arms that mark this place as a site of legal authority.

As with most other criminal courts in Canada, Community Court's jurisdiction is primarily geographic; at least initially, it deals with all persons who have been charged with offences alleged to have occurred within a defined area of downtown Vancouver. From 10 September 2008 to the end of September 2009, this amounted to 2,111 individuals, approximately 62 percent of whom resolved one or more of their cases in that forum. ${ }^{135}$ As Community Court does not conduct trials, persons who choose to contest their charges are transferred to the trial courts at 222 Main Street.

There are two resident judges, and although two courtrooms are available, from my observations only one was ever used; the judges presided in an alternating schedule over different days or weeks. Two Crown counsel also alternated prosecutorial duties during my visits. There is one full-time duty counsel on staff, a rotation of ad hoc duty counsel to assist her work, and various privately retained lawyers shuttling in and out the common door at the rear of the courtroom. In keeping with Community Court's ethos of integrated services, various non-legal professionals are also based at the Court. These include "probation officers, forensic liaison workers, a forensic psychiatrist, a nurse, health-justice liaison workers, employment assistance workers, a victim services worker, a BC Housing support worker and an Aboriginal courtworker." ${ }^{\prime 36}$ These professionals work together in case management teams to offer integrated assistance to individuals who have multiple needs.

Like Court 102, I found Community Court to be a busy place. Moreover, unlike the high volume plea court around the corner, its business included preliminary and procedural matters (including bail, adjournments, and applications) as well as dispositions. I observed 11 hours of proceedings over the course of seven visits, and in that time, only 12 sentencing

Downtown Community Court, Statistical Information (Vancouver: Provincial Court of British Columbia, 2009) at 1, online: Criminal Justice Reform Secretariat <http://www.criminaljusticereform. gov.bc.ca/en/shared/downloads/statistics_through_sept_09.pdf>. Ibid.

British Columbia Ministry of Attorney General, "Vancouver's Downtown Community Court" Backgrounder (6 September 2008), online: Government of British Columbia <http://www2.news.gov. bc.ca/news_releases_2005-2009/2008OTP0218-001343-Attachment1.htm>. 
hearings were completed. This averages out to one each 55 minutes. Controlling for the Court's other business, the average length of the sentencing hearings that I observed in Community Court was 16 minutes, or four minutes longer than at Court 102.

\section{DISCUSSION}

I was interested in gauging how Community Court's distinctive approach, which combines collaborative problem solving with a concern for efficiency, influenced the reflection of restorative values in its sentencing proceedings. In numerical terms, the Court did manifest norm-based communication in every hearing I observed: ten of the 12 contained representations on moral proportionality, two on the offender's normative orientation (or "moral mind") towards the offence, and four featured both. These rates of incidence are higher than those observed in Court 102; most notably, while only five of 22 cases in Court 102 included commentary on the offender's moral mind, six of the 12 hearings that I observed at Community Court explicitly raised this topic.

Before beginning my observations, I thought that Community Court would present a particularly strong model of the participatory engagement I was intent on hearing. The court's guiding principles of "timeliness," "integration," and “connection to community,"137 indeed, are made explicit in its evocation as an innovative justice model.

To a significant extent, my observations validated this presumption, but I also noted some tension between the goals and principles the Court endorses and the reality of its day-to-day operation. Community Court certainly did present as one of the most explicitly expressive of the study courts, at least according to the moral variables of wrongness and responsibility. Offenders themselves appeared to be quite comfortable with speaking in court, neither coerced to do so nor dismissed when they did speak. Sentences themselves were frequently the outcome of joint submissions, although the plea bargaining that lawyers in the Court clearly engaged in did not seem to shut down opportunities for communicative engagement. Most significantly perhaps, when it came to the most serious cases, where an offender was being sentenced to a jail term, the Court and its participants, both lay and professional, appeared to make extra time and effort to practice deliberative decision-making. Offenders spoke most audibly upon moral themes in these cases, which represented a significant difference from those offenders facing similar situations in Court 102. As mentioned above in relation to Court 102, I was also interested in the prevalence of representations on an offender's moral mind in Community Court. From my observations, there was little indication that these statements were being made, by offenders or by their representatives, simply in order to extract a mitigated punishment; rather, the more relaxed, solicitous nature of the Court seemed to facilitate such speech.

Interestingly, the incidence of direct communication from judge to offender was actually higher in Court 102 than Community Court. I observed judges in Court 102 addressing offenders in 18 of 22 hearings, although such addresses incorporated moral themes on only reform_projects/community_court/how_it_works/guiding_principles/index.html>. 
five occasions. At Community Court, judges spoke directly to offenders at sentencing in seven of 12 hearings, with three of these including some amount of speech on wrongness or responsibility. Although there were fewer occasions of direct judge to offender communication at Community Court, a higher proportion of the times that it occurred included statements about the adjudged morality of the offence or offender. Moreover, in a manner that particularly distinguished the operation of Community Court from Court 102, in all of the cases in which probation orders were prepared, the judge would call offenders up to the bench so that he ${ }^{138}$ could personally review with them the terms and conditions of these orders, and confirm their understanding of them.

\section{a. The Court's Focus on Offender Rehabilitation Moderated the Relevance, but Not Incidence, of its Consideration of Wrongness and Responsibility}

A large part of Community Court's mandate concerned the appropriate linking of afflicted offenders to rehabilitative supports that would reduce the risk of reoffending. The court thus assumed an explicitly forward looking orientation, which indelibly coloured deliberations on moral themes relating to the specific conduct that had brought an offender before its gaze. While speech relating to the wrongness of the offence or responsibility of the offender was voiced in every case, it was almost always either overshadowed by, or explicitly linked to, a drug, alcohol, and/or mental health ailment from which the offender was suffering, and to which Community Court had been specifically designed to respond.

\section{b. Third Party and Community Perspectives Were Indirectly Represented}

Community Court did not particularly stand out from the other study courts when it came to the cultivation of victim and community perspectives. In part, this may be because other channels had been provided by the Court for community input and involvement, whether in the broader aspects of its design and operation, or in the fruits of sentencing in the form of community service. ${ }^{139}$ The formal sentencing processes that I observed in Community Court largely retained the same characteristically legal tenor and distribution of participation (with lawyers' voices being by far the most audible) as found in other more orthodox settings. While this arrangement tended, in some cases, to privilege the instrumental concern of efficiency above sustained dialogue on moral themes, it seemed to neither impoverish nor prohibit meaningful opportunities for such expression to develop. On the contrary, these opportunities, although not always taken, were significantly better informed by contextual information (although more about the offender's circumstances than the offence's impact upon others) than I observed to be the case in Court 102. Further, I observed the Crown counsel who appeared in Community Court to be somewhat more interested in articulating the normative concern of proportionality by way of reference to public needs or a victim's experience. Third party perspectives were not, however, central to the Court's deliberations;

139 These avenues of community involvement are mentioned in Community Court's promotional material: see British Columbia Criminal Justice Reform, "Vancouver's Downtown Community Court: Community Connection,” online: Criminal Justice Reform <http://www.criminaljusticereform.gov.bc.ca/en/justice _reform_projects/community_court/connection/index.html>. 
Community Court was unabashedly focused on reducing crime in the community by assisting offenders to stabilize their own lives.

Like all courts, Community Court engaged in the moral ordering of its cases, and did so via both implicit and explicit means. By its willingness to incorporate more information and perspective into a given crime's contextual makeup, it allowed itself more enriched opportunities for moral dialogue about offence and offender. In doing so, however, the Court also encountered pressing instrumental questions about the most appropriate harm reductive response. The apparent tensions between retributive deserts and harm reduction are not, it must be noted, absolute; in many cases they may be resolved through informed deliberation. All in all, although I caught only a brief glimpse into Community Court's approach to the sentencing of criminal offenders, it served to increase my appreciation for its integrative intentions in this regard, and ultimate viability as a restorative forum. My observations led me to believe that, if permitted by the encompassing justice system to develop its methods, resources, and trust, Community Court could become a place where the unmistakable instrumental needs of offenders are addressed in tandem with dialogues on the moral dimensions of a given legal breach.

\section{First NATIONS CoURT}

\section{INTRODUCTION}

First Nations Court is based at the Provincial Court in New Westminster, and, during the period that I observed it, it sat one day per month. It was empowered as is any provincial court to conduct bails, applications, pleas, and sentencing hearings. Its "clients," for lack of a better word, are self-identifying Aboriginal people living in local urban centres, and cases are brought into its purview, upon agreement by the prosecution, from across the Lower Mainland, and sometimes even beyond. First Nations Court has no dedicated facility, official funding envelope, or special support apparatus, being virtually entirely driven by a single judge and a few other committed professionals, with the necessary co-operation of the Office of the Chief Judge of the Provincial Court (to allow for scheduling requirements) and the regional Crown counsel (to facilitate client referrals).

Unlike Community Court, no media backgrounders or information pamphlets were available regarding First Nations Court; it was not included as part of the provincial government's publications regarding its initiatives in the way of criminal justice reform. Indeed, I only heard about its existence by word of mouth. The court that I observed was, nevertheless, unique in the approach it took to the adjudication of offences, and I include it in this study for its distinctive manifestation of communicative engagement with criminal wrongdoing.

I observed ten sentencing hearings at First Nations Court in 20 hours of observation, which were spread over the course of six visits to its monthly sessions from the fall of 2009 through the spring of 2010. This averages to only one completed hearing in every two hours of Court time; a far cry from Court 102's rate of one every 19 minutes. As with Community Court, other proceedings did occupy a significant amount of First Nations Court's business. Controlling for this, the actual average length of the sentencing proceedings that I observed 
was 29 minutes - still almost twice as long as those at Community Court, and more than double the average length of hearings in Court 102. Unlike other courts, however, the largest proportion of First Nations Court's other business consisted not in preliminary procedures, but rather post-adjudication review hearings with offenders who were in the course of serving sentences in the community. The basis for review hearings is located in the Criminal Code ${ }^{140}$ but I never observed them being used in the other study courts. ${ }^{141}$

Over the course of my six visits, First Nations Court occupied three different courtrooms. The first was little more than a small office boardroom, with a single table around which sat all professionals, lay participants, and observers. Although the space was cramped and overcrowded (necessitating the Court's subsequent move to larger quarters), it served well for the environment the judge was intent on fostering. Everyone sat at the same level, looking not just at the judge but at each other. Although we stood as usual when she entered the room in regular judicial robes, the judge proceeded to introduce herself and invite all those present to do the same. Court was concluded with a warm "thank you for coming."

The second sitting that I observed took place in a much larger, traditional courtroom. The judge explained that the move was necessary "because of all the visitors," who on that day included students from a college counselling course, some Aboriginal interns from provincial ministries, and the regular support personnel: two Aboriginal courtworkers, a liaison from the Office of the Chief Judge, and a drug and alcohol counsellor. The clerk invited us to push the tables together to create a more intimate space, and again the judge joined us at this level. The cavernous space, however, made communication difficult. At several junctures the judge mused that she was not "keen" on the space.

The third courtroom the First Nations Court occupied became its regular home, at least over the course of the rest of my visits. It was a smaller, although still regular courtroom, which the Court had attempted to make its own by creating a square of tables for participants to sit around. There was not enough room for observers or supporters, who instead sat on two benches in the public gallery. The judge herself was forced to crane around an inconveniently located pillar to make eye contact with offenders, which she did frequently.

\section{DISCUSSION}

There was much besides environmental idiosyncrasies that I found distinctive about First Nations Court, and which related specifically to my impression of the restorativeness of its approach to sentencing. Below, I discuss the themes that I found most important to understanding how the Court operates. 
a. Offenders Were Engaged in Normative Dialogue, but Not

Necessarily About Wrongness or Responsibility

All of First Nations Court's proceedings featured sustained dialogue between the judge and offender. Lawyers did appear — seven of the sentencing hearings that I observed involved a represented offender - and, of course, Crown counsel was present in every instance to fulfill the state's prosecutorial function, but communication flowed primarily between the judge herself and the individual offender. Out of the three study courts, offenders appearing in First Nations Court were by far the most loquacious, as, indeed, was the judge. Defence counsel appearing in this Court were notably more apt to take on less audible roles as background advisor, as the judge encouraged their clients to speak for themselves.

First Nations Court's unique position among the study courts, as a forum that deliberately selected a certain class of offenders (self-identifying Indigenous persons), allowed for its particularly tailored approach to sentencing. This privilege doubtlessly facilitated First Nations Court's ability to communicatively engage with offenders. The rich conversations that I heard, however, did not include commensurately more speech about a crime's wrongness, or an offender's responsibility, than in the other study courts.

Four of the ten hearings that I observed featured no speech on these themes at all. Six of the ten hearings contained representations regarding the offence's moral proportionality, with four of these including audible references to the offender's normative orientation towards their criminal conduct. The hearings that I observed were, by and large, more centrally concerned with the offender's personal background, circumstances, and future plans. As in the other study courts, although here in its highest rate of incidence, offenders' afflictions occupied centre stage: all ten hearings contained discussion of the person's struggles with drug and/or alcohol abuse, and one of these also included a reference to the offender's mental health. Unlike in the other study courts, however, these issues were rarely explicitly linked to the commission of the offence itself: in only one of the hearings that I observed was addiction mentioned as a motive or contributing factor behind the person's offending.

All ten hearings that I observed shed light on First Nations Court's overarching normative approach to the complexities and sensitivities it encountered in its subjects. Every offender who appeared in the Court was Aboriginal, and all had prior experience in the criminal justice system. Some had very extensive criminal histories, including those whose present offending was only the thinnest manifestation of a mass of personal troubles and afflictions. The judge distinguished herself, and in the process deepened the engagement of those she was sentencing, by her willingness to consider the widest context of why a given person had come before her, and how the Court might help them on their "healing journey." Somewhat like Community Court, but in a more intensely, interpersonal manner, First Nations Court's focus on the person of the offender took precedence over the audible consideration of the offence itself. 
b. The Court Extended Both the Invitation and Expectation to Offenders to Actively Participate in Hearings. Its Focus on Healing Prevailed Over Other Considerations

The construction of sentences that I witnessed in First Nations Court was, as far as the judge could make possible, undertaken jointly with the offender and any other interested lay participants who were in attendance. As the judge told many of those appearing before her for the first time, "I work hard in this Court, and I expect you to do the same." Although challenged to take active part in their own sentencing to a degree not found in the other study courts, only one of the offenders whose hearings I observed seemed less than entirely comfortable with the Court's embrace. As can be observed from this case, when faced with resistance, the Court did not waver from its therapeutic, interventionist approach. The judge took a deeply felt view of the appropriateness of this ethic into each case; unlike in a forum such as Court 102, where this offender would likely have been granted his initial wish to "get this over with,” First Nations Court deliberately inserted itself, with its opportunities and expectations, into the course of people's lives. It is, of course, impossible to prescribe either approach as the correct one in all instances, but the enthusiastic, even eager receptiveness exhibited by most of First Nations Court's clients suggests that the Court's demands are recompensed by its fulfillments.

I also observed the Court encounter, and (gently) repudiate competing ideas of just punishments. The Crown in one case, on fairly standard justificatory grounds, submitted that a punitive, custodial sentence was required for a repeat offender who had committed a fairly significant and sophisticated fraud. The judge, however, engaged with this offender as someone who was already undertaking a healing journey, for whom punishment would offer no purpose. In this sense, First Nations Court's focus was almost exclusively on the needs of perpetrators, not victims (whose views were never considered in the hearings I observed) or countervailing principles of just deserts. Depending upon one's perspective, this approach may arguably trivialize or diminish the moral wrongness of a given crime. Beyond the rather half-hearted resistance offered by the Crown counsel in this one case, however, I did not observe First Nations Court's philosophy in this regard to be seriously challenged. Because it is so up front, lay and professional persons inclined to dispute the Court's approach may simply choose to avoid it. The Court's commitment to offender healing may also effectively bar it from considering more serious cases, given the Crown's control over who is admitted entry.

\section{c. The Court Fashioned Co-operative "Healing Plans," Not Punishments}

A distinctive judicial philosophy was apparent in the First Nations Court's use of language. The reinterpretation of the core concepts of sentencing was audible in all of the hearings that I observed, and was most potently conveyed in the judge's purposeful substitution of the term "healing plan" for "sentence."

I observed the co-operation between the Court's participants to be central to its effectiveness. The judge directed an explicitly problem solving approach, which included all legal and other professionals as resource persons for an offender's healing. Offenders 
themselves were expected to be actively, indeed centrally, involved in this process, and most responded with enthusiasm. I did not observe any adversarial positioning between counsel that obscured this ethic, although in two of ten cases the Crown and defence offered different positions on the appropriate sentence. In both cases the judge inclined towards the defence submission, but in a way that privileged direct dialogic communication between her and the offender.

The judge visibly tried to make everyone in the courtroom feel welcome, and offenders who claimed that they had "never really spoken in court before" were regularly engaged in lengthy dialogues about their background, upbringing, cultural ties, work, and personal lives. Other voices were also heard, whether directly through oral representations (family members, for example, were much more visible and audible in First Nations Court than in other courts, and in one memorable exchange other offenders waiting in the courtroom verbally encouraged the person before the Court for his progress and courage), or in written form. The judge, in particular, made use of Gladue reports. ${ }^{142}$ Five of the ten hearings that I observed included such a report, and in some of the other cases, it was clear that the Court had previously had the benefit of reviewing a pre-sentence report in respect of the offender.

Although I did not observe any victim presence or input (only one of the hearings concerned an interpersonal offence), more than anything else, First Nations Court was a place of lay participation and therapeutic support. It was also a place, not surprisingly, of significantly more Aboriginal involvement and self-direction than what I observed in the other study courts, and not only by offenders. The judge and one of the two regular Crown counsel were Indigenous women, and at least one of the defence counsel who appeared on multiple occasions was Métis.

\section{d. Review Hearings Extended the Court's Influence Over Offenders,} and Offenders' Influence Over the Course of Their Sentences

As mentioned above, sentencing review hearings constituted a substantial part of First Nations Court's proceedings. Those that I observed were varied affairs, sometimes amounting to little more than a five or ten minute chat with the judge about the course of a person's rehabilitation, while others were almost as long and involved as the original sentencing itself, with multiple representations from the offender, service workers, and family or friends. Probation orders were often varied, or shortened, to best meet the offender's adjudged needs, and many of the review hearings I observed were also occasions of heartfelt sharing. Some of the comments that I heard spoke deeply of the First Nations Court's role in changing a person's behaviour or very life. One woman's comment is illustrative: "I'm so grateful I got a conditional sentence in this Court ... I never thought I'd let go of my institutionalization so quickly!”

The judge was effusive in her encouragement of clients who were doing well: "I just want to make sure you're ok ... you've done a great job [so far].” She praised those who had

142 Predicated upon the needs identified in the Supreme Court's decision in Gladue, supra note 59, these are specialized pre-sentence reports that convey information on an offender's Aboriginal background, culture, and circumstances, including any systemic disadvantages they may shoulder as a result. 
reached the end of their orders: “I'm going to miss you — but I don't want you to commit more offences to come back!”

I observed that First Nations Court spent comparatively little of its expressive energy on the wrongness of an offence, and somewhat more on an offender's normative orientation towards their conduct, although only when raised by the offender. The only admonishment I heard the judge make to an individual concerning the actions that had brought them into her purview was rather general, and hardly condemnatory: "When you commit an offence, you show disrespect not only to yourself, but to everyone else.” This is not to imply, however, that the Court did not manifest a powerful normative orientation towards its work, a moral compass that allowed it to make sense of, and respond to, the difficult problems that it encountered. Put in a nutshell, this might be articulated as an engaged awareness of the basic goodness of the persons before it, the manifold personal and social problems behind their offending (none of which were ever referenced as their own fault), and the failure of orthodox criminal justice structures and philosophies to nurture the Indigenous concepts of restoration and healing. The kind of offence and offender focused moral speech that I had come to hear, in this context, often seemed to be besides the real point and purpose of the Court's proceedings.

The Court, as I observed it, did attempt to inculcate responsibility in its subjects, but via an ethos of forward focused healing rather than one of offence focused blame. The sincerity and dedication manifested by those who came before the Court, coupled with the struggles and injustices most had endured on their journeys up to that point, seemed adequate justification for this forum to set aside further inquiries or judgments upon the past. First Nations Court gave little room for assignations of wrongness in respect of either act or actor. Although the absence or overshadowing of such discussion disconcerted me at times, especially in light of what I theorized criminal jurisdiction and authority to centrally concern, First Nations Court's approach ultimately convinced me of its suitability. In cultural terms, this suitability was most pronounced for the Indigenous persons who had previously been subject to so many of the justice system's presumptions of appropriate treatment; these individuals had clearly suffered personal harm from these experiences, just as their nations and traditions had suffered harm from similar presumptions applied on a wider scale. First Nations Court deliberately placed Indigenous actors and approaches at the centre of its practice.

The Court also seemed to offer a defensible approach to any offender willing and able to accept meaningful responsibility for their past and future conduct. This conclusion has both practical and normative aspects. In regards to the former, my observations convinced me that the Court's encouragement and supervision of offenders represented the most helpful and effective kind of community-based sentence. On moral grounds, the Court's approach seemed generally suitable for those whose offending was the result of past harm, and which involved as much, if not more, self-harm than it did harm to others. Healing, in these circumstances, has a persuasive claim as the most just response, although it need not be the exclusive one. 


\section{CONCLUSION}

This study has grouped these three courts together to gauge their ability to substantively engage with offenders, especially in regards to the themes of wrongness and responsibility. These observations, I presumed, would in turn give me some idea of the restorative merits of these varied approaches to resolving wrongdoing within a state-based criminal justice system.

As noted, none of the processes that I observed evidenced much in the way of victim input, let alone participation. The restorative impact of these models, at least as measured according to Zehr's six questions, was thus considerably attenuated from the outset.

It further became clear through my observations that the mere audibility of representations on the gravity of an offence and the degree of responsibility of an offender did not always mean that an offender was actively participating, or that professional participants were using more than rote heuristics to contextualize a given legal breach. As First Nations Court, in particular, challenged me to conclude, the reverse was also possible: sentencing hearings need not explicitly take up the themes of wrongness and responsibility (at least as interpreted as referring solely to the offence itself) in order to exert powerful normative force, and can indeed reflect alternate understandings of what is most important about this offence and this offender. Indeed, in terms of offender engagement in the construction of case outcomes, First Nations Court was clearly the most facilitative. It did so by hardly looking at the particular wrong for which a person was being sentenced, instead devoting its consideration to broader contextual factors and the offender's future prospects.

In terms of formal admissions of responsibility, I found that guilty pleas themselves were rarely employed as indicators of an offender's understanding of, and/or orientation towards their conduct (and, as others have argued, there may be good reasons not to interpret them as such ${ }^{143}$ ), and neither were they often used as opportunities to probe into the meaning(s) that a plea conveys. A judge's reluctance to ripple the surface of these communications, whether due to the influence of plea bargaining, ${ }^{144}$ caseload pressures, or a simple lack of concern for further inquiry, did not necessarily lead to sentencing hearings that lacked the engaged participation of offenders. None of the ten hearings in First Nations Court, for example, audibly considered the offender's plea, but all ten featured engaged communication. Guilty pleas were explicitly referenced, by contrast, in seven of the 22 hearings that I observed in Court 102. They tended to be employed in this latter forum, however, more as cursory indications of an offender's remorse or the plea's benefits in conserving court resources; judges neither asked for nor received further elaborations on the context of an offender's guilty plea. Defence Lawyer: Negotiating Guilt and the Economics of 21st Century Criminal Justice” (2005) 50 Crim. L.Q. 108 at 125.

144 The presence and influence of plea bargaining cannot be comprehensively assessed through an observational study such as this one. I can note, however, that joint submissions on sentence, one of plea bargaining's key indicators, were made in 27 of the 44 hearings that I observed, and accepted in 22. 
From the preponderance of these findings, I can conclude that guilty pleas are not well used, or, in the pressured and obfuscating context in which they are often conveyed, particularly useful vehicles of normative communication. When it comes to plea-based courts, a plea simply gets offenders "through the door"; what happens thereafter depends, as is explored below, on a constellation of factors.

\section{SPEED KILLS: OFFENDER ENGAGEMENT BENEFITED FROM A COURT'S PREPARATION AND PATIENCE}

My observations of Court 102 showed it to be a forum confronted with a relatively high quantity of hearings, and motivated to dispense with its sentencing obligations as efficiently as practicable. This orientation, which may be defended as in the instrumental interest of all Court 102's constituents, lay as well as professional, did not, as I observed, prohibit speech upon the themes of wrongness and responsibility. It did, however, seem to constrain the ability of offenders to audibly engage in the quickly constructed and resolved narratives that occurred in the course of short hearings.

The explicitly rehabilitative, harm reductive ethic that I observed at Community Court, by contrast, did provide somewhat more space for communications upon these themes to be shared amongst participants. Hearings were longer, counsel more contextually well versed and informed, and offenders apparently more able and/or willing to voice their perspectives. Interestingly, the judges at Community Court spoke less upon the themes of wrongness and responsibilty than I expected, perhaps due to the Court's abiding concern with instrumental goals - here, less in terms of strict efficiency than in solving the problems contributing to the commission of offences.

First Nations Court, for its part, was equally intent on problem solving, but in a way that focused on what may be called the cultural, even spiritual, worth and integrity of its clients, as well as their particular instrumental needs. This afforded an abundance of communicative, therapeutic engagement, but little speech on wrongness or responsibility per se. Instead, the engagement that I observed in this forum seemed to represent, perhaps, an essential (and, in other courts, arguably overlooked) precursor to the explicit deliberation upon the wrongness of a criminal act. For me, the suffering and alienation manifest in the stories that First Nations Court encountered fundamentally informed its normative orientation. The Court's manifest emphasis on an offender's integrated healing coloured, and often eclipsed, any audible focus on the themes that I had set out to listen for. Whether this focus manifests a remedial approach to the sentencing of Aboriginal offenders, an Indigenous concept of the most appropriate way to right wrongs, or a combination of the two, cannot be conclusively addressed here. Here, I only suggest that my observations of this Court's practices showed that its patient, supportive framework for the development of offenders' voices did allow for a rich depth of restorative engagement. This finding is expanded on below.

\section{OFFENDERS WERE MOST LIKELY TO SPEAK WHEN THE CONTEXT SUPPORTED IT}

The audibility of offenders was a core, virtually essential aspect of the restorativeness that I tried to measure in this study. I presumed that when offenders' voices are heard, sentencing 
courts are more likely to be normatively communicative, restorative enterprises, and vice versa. In testing this presumption, I found that each study court presented different conditions and opportunities for offenders to speak.

The most supportive forum in terms of offender speech was First Nations Court; every offender in this Court made substantive representations. By contrast, eight of 12 offenders spoke at their hearings in Community Court, as did 12 of 22 at Court 102. The distribution of speech by offenders who were identifiably Aboriginal was particularly interesting. In Court 102, only one of the five Aboriginal offenders whose hearings I observed made an audible representation. Two of three made representations at Community Court, and, of course, all of those at First Nations Court did so. This (very limited) observation indicates, for me, that Court 102 presented a particularly difficult environment for Aboriginal offenders to personally impart their perspectives. This observation does not mean, of course, that Court 102 represses or is consciously hostile to the engagement of Aboriginal offenders. Indeed, I did not notice any difference in the way that such cases were conducted, beyond defence counsel submissions on an offender's background and the occasional passive presence of an Aboriginal courtworker. In particular, I did not observe any of the directives contained in the Supreme Court of Canada's Gladue decision to be reflected in Court 102's practices in regards to Aboriginal offenders. This Court's formal equality in terms of procedural treatment, however, did result in a measurably different level of audibility as between Aboriginal and non-Aboriginal offenders.

\section{OFFEndERs EXPRESSED REMORSE MOST OFTEN When OutCOMES WeRE UnCERTAin, AND WHEN A JAIL SENTENCE WAS POSSIBLE}

I was particularly interested in discerning influences upon the expression of an offender's moral orientation towards their conduct (in practical terms, acknowledgments of remorse or regret). As noted above, I thought that these expressions would be important indicators of a court's viability as a forum for normative, restorative engagement. My findings, however, disclosed stronger evidence that remorse was raised most often as a means of pleading for a court's lenience or understanding in circumstances where it held (or was thought to hold) instrumental advantages for an offender's sentence.

In regards to Court 102, I observed that expressions of remorse only occurred when an offender was in custody and facing a possible jail sentence (three instances). For me, this is an indication of the expectation borne by offenders in this forum that there is only an instrumental rationale (that is, the possibility of a more lenient sentence) for speaking about their orientation towards their conduct. This theory applied, to a slightly weaker degree, at Community Court as well: while eight of 12 offenders spoke, two of the three who made statements of remorse were in custody and facing the possibility of further jail.

Expressions of remorse or regret were not commonly voiced in First Nations Court; only two of ten offenders made such comments. I interpreted this relatively low incidence to be due, in large part, to the forward looking focus of the dialogic engagement that the judge encouraged. The prosecutor actively or passively acquiesced to this orientation in most cases; it seemed an acknowledged aspect of this Court's animating ethos. But in both instances, 
where an offender did speak of their moral mind in regards to the offence, the Crown had first made explicit, critical reference to the circumstances of their offending.

In general terms, my observations indicated that an offender's articulation of the moral responsibility they felt for a given wrongdoing stemmed from direct or indirect prompting by professional participants and/or the uncertainty of outcome. Expressions of remorse were not spontaneously given.

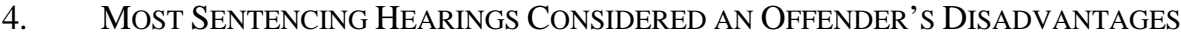 OR AFFLICTIONS; IT WAS A MAJOR TOPIC OF A CRIME'S “WRONGNESS” IN ALL COURTS EXCEPT FIRST NATIONS COURT}

One of the most noticeable topics raised in the sentencing hearings that I observed concerned the offenders' struggles with substance abuse and/or mental health issues. Out of 44 hearings, the matter was raised in 38. Looking more closely at the numbers, problems related to substance use were brought up in 33 cases, while mental health issues were raised in nine. These figures include four cases where the offender's substance use and mental health were both raised as relevant considerations for the sentencing judge. Most of these representations were made by defence counsel in aid of mitigation.

There was noticeable variability across the study courts in terms of how these issues were considered. While substance use and/or mental health were raised in all ten cases in First Nations Court, they were spoken of in relation to the charged offence(s) in only one instance. By contrast, the same issues were voiced as speech related to wrongness or responsibility in ten of the 11 hearings in which they were considered at Community Court and 11 of 17 in Court 102.

Clearly, all of the study courts, and very likely all sentencing courts generally, frequently hear representations about the afflictions or disadvantages that contribute to offenders appearing before them. The more important question is how they are interpreted and responded to. My observations indicate that Community Court was particularly attuned to the causal factors relating to the particular breach for which an offender was being sentenced, while First Nations Court represented an approach that equally considered these "contributory disadvantages," but in such a way as not to audibly emphasize a connection between offenders' afflictions and their particular crimes. All three courts seemed to accept that such considerations were relevant to their sentencing work, but discharged this recognition in various ways. Community Court most explicitly harnessed its dispositions to the problems of substance abuse and/or mental illness; in this forum, more so than in the others, most speech on the theme of a crime's wrongness concerned the appropriate calibration of causal factors to case outcomes. Offenders themselves were not particularly engaged in such discussions. In First Nations Court, by contrast, I observed offenders to take more active participation in speech involving issues of substance abuse.

This study has shown that different courts, while operating in the same legal environment, and encountering similar offences and offenders, do have different ranges and volumes when it comes to the audibility of offender engagement at sentencing. The factors that influence this engagement are, in turn, susceptible to the control or influence of a number of forces. 
Without presuming to exhaustively enumerate or classify these forces, I found that a sentencing court's engagement of offenders in its normative work did depend, in part, on the willingness of offenders themselves. Simply put, without some active interest on the part of these lay participants, courts are less likely to put significant time and energy into cultivating offenders' narratives and normative views. I observed that the time and energy that individual courts invest in this regard, however, is even more responsible for communicative engagement than qualities intrinsic to offenders. These two variables are impossible to fully parse, of course, but my observations showed that a court that exhibits care and attention towards the moral dimensions of an offence or offender is more likely to cultivate engagement, even among initially reluctant offenders, than a court that is impatient or apparently unconcerned with these matters. A court's character in this regard is formed most importantly by its presiding judge, but also influenced by Crown and defence lawyers as well as supporting professionals. Finally, the overarching intentions and decisions of the justice system itself contribute to the design of the justice that courts perform. As this study has demonstrated, sentencing hearings can be forums for in-depth dialogue and intense moral expression, just as they can be exercises in shallow formalism. In terms of subjective considerations of the "restorativeness" of a process, while it is clear that none of the practices that I observed offered comprehensive possibilities in this regard, those that manifested qualities of engagement and expression gave far more chances for offenders to experience restorative benefits than those that focused on efficiency or final outcomes.

\section{Conclusion}

There are at least two major reasons why court-based resolution processes are presumptively non-restorative. The first, as discussed in Part II, is the retributive ethic upon which these forums are founded. When the overriding business of a sentencing hearing is the discernment and imposition of punishment (however "just”), it is no small wonder that wrongdoers may be further separated from, or even rejected by, the normative community in whose name they are punished. While the formal expectation of the law may be for punishment to bring about an offender's eventual reintegration, this salutary effect is not commonly privileged as among the court system's primary responsibilities.

Even given this ideological handicap, however, Part II of this article also took pains to point out some equally fundamental opportunities for communication and expression that are embedded in the governing law. If restorative values are to adhere in the state-based criminal justice system, I argued, it is through means such as victim participation and offender allocution that this would be accomplished. However, it is by inspecting these very opportunities that the second major impediment to a sentencing court's restorativeness can be found. As Part III related, there are a constellation of instrumental and cultural forces that tend to overshadow formal openings for lay engagement, from the plea of guilt itself to a judge's final deliverance of the sentence.

It is within this mixed context of opportunities and obstacles that my empirical research inquired into what insights might be gathered from the observation of specific courts, orthodox as well as innovative. Not surprisingly, I drew some quite mixed conclusions from this study. The hearings that I witnessed could not easily be classified into the categories of "retributive" or "restorative.” As Zehr and others have recognized, these concepts of justice 
are not necessarily opposed. Indeed, the methods espoused by the latter philosophy have much to offer for the effective expression of the former's message. This is particularly true in situations where an offender's pre-existing ailments or alienation stand in the way of, and indelibly colour, a court's interest in harnessing the themes of wrongness and responsibility. In the overall picture of state-based criminal justice, these themes are likely to remain predominant concerns, but unless sensitively and contextually interpreted by local sentencing courts, they are unlikely to resonate with local perspectives, realities, and needs. Beginning (and, given this study's parameters, necessarily ending) with offenders themselves, I asked how a selection of courts were engaging with these concerns, and what glimmers of restorative value could be discerned therein.

In very general terms, while Court 102 conveyed the straight talk of moral ordering expected of a busy, orthodox plea court, it was not much interested in an offender's response. Accordingly, very few conversations of this nature were attempted. Community Court manifested somewhat more interest in the moral messages of its process and product, but most communicative exchanges were coloured by that forum's focus on instrumental problem solving. First Nations Court, for its part, offered a substantively different, and arguably richer, manifestation of moral ordering than that which I had theorized. This Court engaged offenders as persons in need of guidance and support as they reconstructed healthy identities. The normative language audible in this forum was not so much intent on calibrating blame as sharing wisdom, whether as won from a judge's perspective, or from the hard experience of being judged.

None of the hearings that I observed embodied an ideal restorative practice, wherein the normative and practical dimensions of wrongdoing are comprehensively enunciated, not merely with regard to court and offender perspectives, but including those of victims and community representatives. It is unlikely that any sentencing court, given the many constraints I have noted as impinging upon their work, could ever sustain such expressiveness. Indeed, as First Nations Court in particular taught me, there is not, and perhaps in a flexible justice system need not be, one overarching ideal or appropriate practice in the resolution of criminal wrongs. That said, the most communicative hearings were those least fettered by the law's expectations of uniformity, and most creative in their use of the law's discretion.

Canada's state-based, plea court oriented system of criminal justice is a difficult place to locate and practice restorative values. As I hope this article has conveyed, however, there are numerous cracks in its non-restorative facade through which considerable light may be perceived to shine for the harnessing of courts with the courage and conviction to make the effort. 